\title{
Ionic Liquid as Reaction Media for the Production of Cellulose-Derived Polymers from Cellulosic Biomass
}

\author{
Joana Maria Lopes, María Dolores Bermejo *, Ángel Martín and María José Cocero \\ High Pressure Processes Group, Department of Chemical Engineering and Environmental Technology, \\ University of Valladolid, C/ Doctor Mergelina s/n, 47011 Valladolid, Spain; joana.lopes@gmail.com (J.M.L.); \\ mamaan@iq.uva.es (A.M.); mjcocero@iq.uva.es (M.J.C.) \\ * Correspondence: mdbermejo@iq.uva.es; Tel.: +34-983-184-077
}

Received: 28 July 2017; Accepted: 17 October 2017; Published: 23 October 2017

\begin{abstract}
The most frequent polymer on nature is cellulose that is present together with lignin and hemicellulose in vegetal biomass. Cellulose can be, in the future, sustainable raw matter for chemicals, fuels, and materials. Nevertheless, only $0.3 \%$ of cellulose is processed nowadays due to the difficulty in dissolving it, and only a small proportion is used for the production of synthetic cellulosic fibers especially esters and other cellulose derivatives, normally in extremely polluting processes. The efficient and clean dissolution of cellulose is a major objective in cellulose research and development. Ionic liquids (ILs) are considered "green" solvents due to their low vapor pressure, that prevents them evaporating into the atmosphere. In addition, these molten salts present advantages in process intensification, leading to more than 70 patents in lignocellulosic biomass in ILs being published since 2005, most of them related to the production of cellulose derived polymers, e.g., acetates, benzoylates, sulfates, fuorates, phthalates, succinates, tritylates, or silylates. In this work, the use of ILs for production of cellulose derived polymers is thoroughly studied. To do so, in the first place, a brief summary of the state of the art in cellulose derivatives production is presented, as well as the main features of ILs in cellulose processing applications. Later, the main results in the production of cellulose derivatives using ILs are presented, followed by an analysis of the industrial viability of the process, considering aspects such as environmental concerns and ILs' recyclability.
\end{abstract}

Keywords: cellulose; ionic liquids; cellulose derivatives; acetylation

\section{Introduction}

Cellulose is a natural biopolymer, being the most common organic polymer and main component of cell wall in plants. Natural global production is about 40 billion tons per year, of which three-tenths of a percent is used by the pulp industry [1]. Cellulose is a homopolysaccharide of $\beta(1 \rightarrow 4) \mathrm{D}$-glucosyl residues, resulting in a linear chain polymer composed of anhydrous glucose units (AGU) (Figure 1), each one containing three hydroxyl groups [2] able to form hydrogen bonds. Inner cohesion of crystalline regions is due to the van der Waals attraction between hydrogen-bonded sheets [3]. The crystal structure of cellulose varies with its origin (cellulose crystallinity can be 90-100 g/100 g cellulose in plant-based fibers and 60-70 g/100 g cellulose in wood-based fibers) and chemical or physical treatment (e.g., milling and hydrolysis) [4]. The chain length is expressed by the number of AGUs that is called degree of polymerization (DP). Therefore, cellulose of different origin, DP and index of cristallinity (Ic) is expected to require different dissolution/reaction conditions, due to the effect of these parameters on the accessibility to hydroxyl groups.

In nature, cellulose can be found as a part of lignocellulose, that mainly contains cellulose (40-50\%), hemicellulose (20-40\%), and lignin (20-30\%) [5]. While cellulose and hemicellulose are composed of covalently linked and hydrogen bonded carbohydrate polymers, lignin consists of a net of phenolic polymers, forming a substance that is not soluble in water and conventional solvents. 


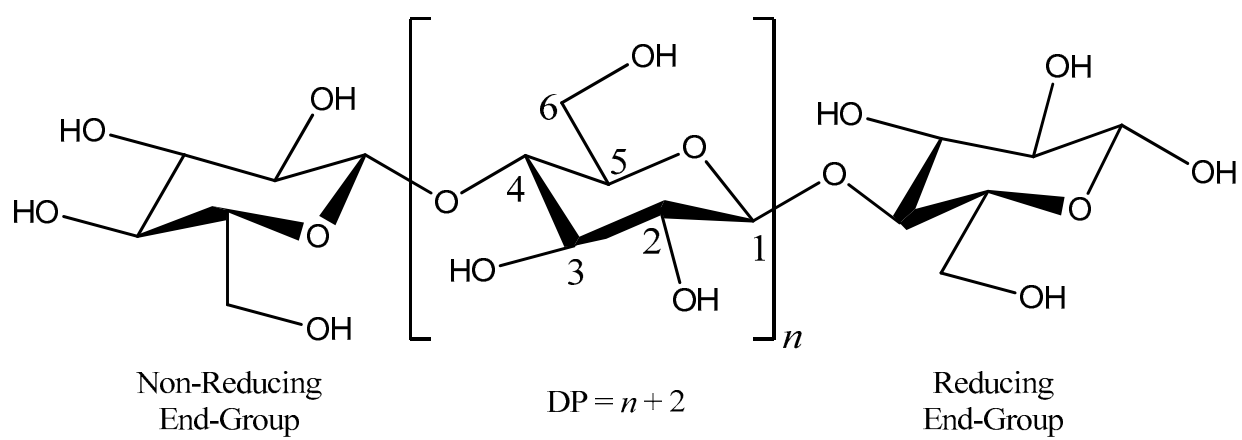

Figure 1. Cellulose structure.

The main cellulose resources are forestry, agriculture crops, industrial, food, and garden waste [6]. Wood pulp remains the main raw material source for the processing of cellulose, most of it being used for the production of paper and cardboard after partial removal of the non-cellulosic constituents from its original fiber form [7]. The use of organic solvents (e.g., ethanol, methanol, ethylene glycol, acetic acid, formic acid) for cellulose isolation and processing [8] is associated with higher pretreatment temperature, use of catalysts, toxicity, and inflammability issues. Thus, for the realistic use of cellulose as an extensive natural resource, it will be necessary to develop a platform that uses this natural polymer for the production of environmentally friendly and biocompatible products [9]. Therefore, development of alternative solvents for the efficient dissolution and transformation of lignocellulose into value-added products is necessary. Promising solvents for cellulose processing are the ionic liquids (ILs) [10-13].

\section{Dissolution of Cellulose in ILs}

\subsection{ILs}

ILs are organic salts containing only ions that are fluid at room temperature (usually defined as fluid below or around $100{ }^{\circ} \mathrm{C}$ ) [14]. One of ILs' characteristics is their extremely low vapor pressure, below their decomposition temperature. Due to this property, they cannot pollute the environment by evaporation, unlike the organic solvents [15]. Furthermore, most ILs are non-flammable and have relatively high thermal stability, compared with organic solvents [16]. A number of studies about the properties of the ILs can be found in literature [17-20].

Different ILs with tunable properties can be synthesized by selection of their anion and cation. ILs present high solvation properties for a number of substances, e.g., water, methanol, acetone, chloroform, acetic anhydride, toluene, both polar and apolar, and even polymeric substances such as cellulose [21]. Many ILs present catalytic activity, and are able to stabilize catalysts and enzymes [22,23]. The properties of ILs can be adjusted by the variation of the size chain of the cation and variation of anion due to the changing polarity and size [24]. Several preparation procedures (e.g., direct quaternization, reaction of halide with Lewis acid, anion exchange) have been reviewed by Wasserscheid and Keim [25]. More recent reviews on synthesis of ILs can be found in literature, e.g., biocompatible ILs [26], ether, and alcohol functionalized ILs [27], or poly(ionic liquid)s [28]. It is worth noting that the label "green solvent" does not mean that all ILs are non-toxic [29]. An update on ILs use as solvents in synthesis and catalysis has been published by Hallett and Welton [30] and by Steinrück and Wasserscheid [31]. The structures of the main cations and anions described in literature are shown in Figure 2.

Salts based on the dialkylimidazolium, pyrrolidinium, and pyridinium cations have gained attention because of the wide spectrum of physicochemical properties [32-36], such as melting points, viscosities, densities, surface tension, refractive indices, and miscibilities with polar and nonpolar solvent. These properties can be affected by water, halides, and metals, which are the most prevalent 
impurities present in ILs [37]. The presence of water can occur due to hygroscopicity, whereas other impurities mainly come from the mode of preparation of the IL. Thus, ILs prepared by identical reactions but provided by different suppliers can give different results, due to the presence of small concentrations of different impurities [38]. Methods for preparation of ILs and purity determination (in most cases by ${ }^{1} \mathrm{H}$ and ${ }^{13} \mathrm{C} \mathrm{NMR}$ ) are proposed in literature [39]. Additionally, methods for producing large quantities of high quality ILs propose simple techniques to determine the purity of the final product e.g., UV-vis spectroscopy for optical purity [40] and colorimetric determination of 1-methylimidazole in the range 0-3 mol \% [41]. Recently, real-time monitoring of 1-methylimidazole concentration through LED-based optical sensor and photodiode detectors was achieved with detection limit of $4 \mathrm{~mol} \%$ [42].

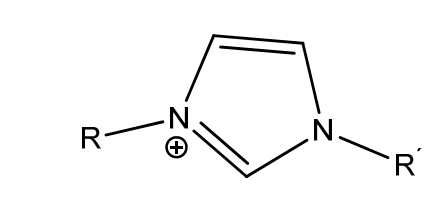

N-alkyl-N-methyl-imidazolium

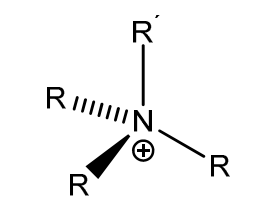

tetraalkyl-ammonium<smiles></smiles>

N-alkyl-pyridinium

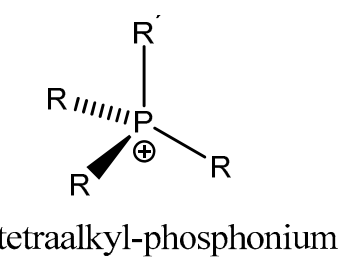

$\mathrm{Cl}^{-}, \mathrm{Br}^{-}, \mathrm{I}^{-}$

$\left[\mathrm{PF}_{6}\right]^{-},\left[\mathrm{BF}_{4}\right]^{-}$

$\left[\mathrm{CF}_{3} \mathrm{CO}_{2}\right]^{-},\left[\mathrm{CF}_{3} \mathrm{SO}_{3}\right]^{-}$

$\left[\mathrm{HSO}_{2}\right]^{-},\left[\mathrm{RSO}_{4}\right]^{-},\left[\mathrm{RSO}_{3}\right]^{-}$

$\left[\mathrm{H}_{2} \mathrm{PO}_{3}\right]^{-},\left[\mathrm{R}_{2} \mathrm{PO}_{4}\right]^{-}$

$\left[\mathrm{CH}_{3} \mathrm{CO}_{2}\right]^{-}$

Figure 2. Typical cations and anions forming ionic liquids (ILs) described in literature [31].

\subsection{Mechanism of Cellulose Dissolution}

The first to dissolve cellulose in ILs were Swatloski et al. [43], opening new opportunities for the processing of this and other biopolymers, such as lignin [44-46] or chitin [47-49]. It was demonstrated that cellulose can be dissolved at concentrations up to $25 \%(w / w)$ in imidazolium-based ILs with chloride anions. Since then, a number of ILs have been found to be able to dissolve cellulose [50-54]. The most studied cations for cellulose dissolution are based on the imidazolium, pyridinium and pyrrolidinium cores, with allyl-, ethyl-, or butyl-side chains, and the most promising anions, apart from chloride, are acetate, formate, and alkylphosphate. However, chloride-based ILs with longer chain substituted imidazolium cations are less efficient in cellulose dissolution [43].

Cellulose dissolution results from the solvent's ability to eliminate the inter- and intra-molecular hydrogen bonds among biopolymer molecules. The predominant mechanism of this dissolution process is found to be the formation of hydrogen bonds between the anions of the ILs and the hydroxyl groups of the biopolymer, with no specific role for the cation [55-58]. However, it can also be found that the driving force of cellulose dissolution should be a result of the joint interactions of anions and cations with cellulose [59-61]. Computer simulations were carried out to support this [62].

Cellulose maintains its original chemical structure or forms a complex with the solvent only by intermolecular interactions (no covalent interactions occur) [63], thus, ILs are part of the so called non-derivatizing solvents [64] that include, for example, aqueous solution of sodium hydroxide [65], N,N-dimethylacetamide/lithium chloride (DMA/LiCl) [66,67], dimethylsulfoxide (DMSO) in combination with ammonium fluorides [68-71], and $N$-methylmorpholine- $N$-oxide (NMMO) [72]. There are a number of derivatizing solvents (able to dissolve cellulose with substitution, forming new covalent bonds) e.g., trifluoroacetic acid (TFA) [73], sodium hydroxide/carbon disulfide $\left(\mathrm{NaOH} / \mathrm{CS}_{2}\right)$ [74], and $\mathrm{N}, \mathrm{N}$-dimethylformamide/dinitrogen tetroxide [75]. 
A number of works, including several reviews [76-82], have been already published on the cellulose dissolution process in ILs. Thus, this subject will not be discussed in depth in this review. However, for understanding of the dissolution process of cellulose in ILs in relation with its industrial application, it is important to mention the solvent properties: hydrogen bond basicity, viscosity, and water content.

\subsection{Hydrogen Bond Basicity of Cellulose Dissolving ILs}

ILs with high ability to form hydrogen bonds (hydrogen bond basicity) weaken the inter- and intra- molecular hydrogen bonds of cellulose structure, causing its dissolution [83]. Thus, the efficiency of these processes is usually improved with increased basicity of the ILs. The hydrogen bonding ability can be quantified by the Kamlet-Taft parameters [84], which specify three distinct polarities: hydrogen-bonding acidity $(\alpha)$, hydrogen-bonding basicity $(\beta)$, and dipolarity/polarizability $\left(\pi^{*}\right)$. All three protons of the imidazolium ring are acidic, with the 2-position proton being the one that contributes more to the hydrogen-bonding acidity [85]. A study [86] on imidazolium-based ILs reported $\pi^{*}$ variation with both anion and cation, $\alpha$ dependence mainly on the cation and $\beta$ value, in general, affected mainly by the nature of the anion species. $\beta$ values of ILs with the same cations vary with the anion structure, as shown in Table 1. Chloride-based ILs are potential solvents for cellulose (e.g., $\beta_{[\mathrm{Bmim}] \mathrm{Cl}}=0.95$ ), as the chloride anion is a strong proton acceptor in the interaction between hydroxyl groups of cellulose. Nevertheless, the high melting temperature and high viscosity makes their use expensive and inefficient. As an alternative to conventional ILs, polar ILs with low melting points and relatively low viscosities, such as dialkylimidazolium salts with phosphate-, acetate-, and formate-derived anions have been studied [87]. Some [Bmim]-based ILs containing carboxylic anions (Ac and $\mathrm{HCO}_{2}$ ) were reported [88] to show stronger hydrogen-bonding basicity $\left(\beta_{[\mathrm{Bmim}] \mathrm{OA}_{\mathrm{C}}}=1.09, \beta_{[\mathrm{Bmim}]} \mathrm{HCO}_{2}=1.01\right)$ than chloride anion. The methylphosphonate anion salts with stronger hydrogen bond basicity than conventional ILs are able to dissolve $2.0 \mathrm{wt} \%$ of cellulose powder within $3 \mathrm{~h}$ at room temperature [88] $\left(25^{\circ} \mathrm{C}\right)$ and within $30 \mathrm{~min}$ at $45^{\circ} \mathrm{C}$ [89]. In general, polar ILs are very hygroscopic, however, almost no correlation has been found between $\pi^{*}$ and hygroscopicity of [mim]-based ILs [90]. ILs with other anions presenting low basicity, such as those with bromide $\left(\beta_{[\mathrm{Emim}] \mathrm{Br}}=0.87\right)$, trifluoroacetate $\left(\beta_{[\mathrm{Emim}] \mathrm{CF}_{3} \mathrm{CO}_{2}}=0.74\right)$, thiocyanate $\left(\beta_{[\mathrm{Emim}] \mathrm{SCN}}=0.71\right)$, methanesulfonate $\left(\beta_{[\mathrm{Emim}] \mathrm{M}_{\mathrm{e}} \mathrm{SO}_{3}}=0.70\right)$, or tetrafluoroborate $\left(\beta_{[\mathrm{Bmim}] \mathrm{BF}_{4}}=0.38\right)$ anions show [83] cellulose solubilities $<1 \%$ in mass.

Table 1. ILs capable of dissolving cellulose (modified from [83] and molecular-microscopic properties measured at $25{ }^{\circ} \mathrm{C}$ : hydrogen-bonding acidity $(\alpha)$, hydrogen-bonding basicity $(\beta)$, dipolarity/polarizability $\left(\pi^{*}\right)$ and physical properties: viscosity at $25{ }^{\circ} \mathrm{C}(\eta)$, melting temperature $(\mathrm{Tm})$, decomposition temperature (Tdec).

\begin{tabular}{|c|c|c|c|c|c|c|c|c|c|c|}
\hline \multirow{2}{*}{$\begin{array}{c}\text { ILs (Cellulose } \\
\text { Solubility }>1 \%)^{1,2}\end{array}$} & \multirow{2}{*}{$\begin{array}{c}\eta \\
(\mathrm{mPa} \cdot \mathrm{s})\end{array}$} & \multirow{2}{*}{$\begin{array}{l}\mathrm{Tm} \\
\left({ }^{\circ} \mathrm{C}\right)\end{array}$} & \multirow{2}{*}{$\begin{array}{l}\text { Tdec } \\
\left({ }^{\circ} \mathrm{C}\right)\end{array}$} & \multicolumn{3}{|c|}{ Kamlet-Taft Parameters ${ }^{3}$} & \multirow{2}{*}{ Ref. } & \multirow{2}{*}{$\begin{array}{l}\text { ILs (Cellulose } \\
\text { Solubility < } 1 \% \text { ) }\end{array}$} & \multirow{2}{*}{$\beta$} & \multirow{2}{*}{ Ref. } \\
\hline & & & & $\beta$ & $\alpha$ & $\pi^{*}$ & & & & \\
\hline$[\mathrm{Amim}] \mathrm{Cl}$ & 2090 & & 256 & 0.83 & 0.46 & 1.17 & [87] & {$[\mathrm{Bmim}] \mathrm{BF}_{4}$} & 0.38 & [86] \\
\hline$[$ Emim $] \mathrm{HCO}_{2}$ & & 52 & 212 & & & & [87] & {$[\mathrm{Bmim}] \mathrm{PF}_{6}$} & 0.21 & [86] \\
\hline$\left[\right.$ Prmim] $\mathrm{HCO}_{2}$ & 117 & & & 0.99 & 0.48 & 1.08 & [87] & {$[\mathrm{Emim}] \mathrm{MeOSO}_{3}$} & 0.61 & [89] \\
\hline$[\mathrm{Amim}] \mathrm{HCO}_{2}$ & 66 & & 205 & 0.99 & 0.48 & 1.08 & [87] & {$\left[\right.$ Emim] $\mathrm{MeSO}_{3}$} & 0.70 & [89] \\
\hline
\end{tabular}


Table 1. Cont.

\begin{tabular}{|c|c|c|c|c|c|c|c|c|c|c|}
\hline \multirow{2}{*}{$\begin{array}{c}\text { ILs (Cellulose } \\
\text { Solubility }>1 \% \text { ) }\end{array}$} & \multirow{2}{*}{$\begin{array}{c}\eta \\
(\mathrm{mPa} \cdot \mathrm{s})\end{array}$} & \multirow{2}{*}{$\begin{array}{l}\mathrm{Tm} \\
\left({ }^{\circ} \mathrm{C}\right)\end{array}$} & \multirow{2}{*}{$\begin{array}{l}\text { Tdec } \\
\left({ }^{\circ} \mathrm{C}\right)\end{array}$} & \multicolumn{3}{|c|}{ Kamlet-Taft Parameters $^{3}$} & \multirow{2}{*}{ Ref. } & \multirow{2}{*}{$\begin{array}{l}\text { ILs (Cellulose } \\
\text { Solubility < } 1 \% \text { ) }\end{array}$} & \multirow{2}{*}{$\beta$} & \multirow{2}{*}{ Ref. } \\
\hline & & & & $\beta$ & $\alpha$ & $\pi^{*}$ & & & & \\
\hline [Bmim]OAc & & & & 1.09 & 0.55 & 0.99 & [88] & {$[\mathrm{Emim}] \mathrm{CF}_{3} \mathrm{CO}_{2}$} & 0.74 & {$[91]^{4}$} \\
\hline$[\mathrm{Bmim}] \mathrm{Cl}$ & & 66 & 254 & 0.95 & 0.47 & 1.10 & [91] & [Emim]SCN & 0.71 & [91] \\
\hline$[\mathrm{Bmim}] \mathrm{HCO}_{2}$ & & & & 1.01 & 0.56 & 1.03 & [88] & {$\left[\right.$ Emim] $B_{4}$} & 0.55 & {$[91,92]^{5}$} \\
\hline$[\operatorname{Emim}](\mathrm{MeO})_{2} \mathrm{PO}_{2}$ & 265 & 21 & 289 & 1.00 & 0.51 & 1.06 & [89] & {$[\mathrm{Emim}] \mathrm{N}(\mathrm{CN})_{2}$} & 0.64 & [91] \\
\hline$[\mathrm{Emim}](\mathrm{MeO}) \mathrm{HPO}_{2}$ & 107 & & 275 & 1.00 & 0.52 & 1.06 & [89] & {$[$ Emim]I } & 0.75 & [91] \\
\hline$[\mathrm{Emim}](\mathrm{MeO}) \mathrm{MePO}_{2}$ & 510 & & 262 & 1.07 & 0.50 & 1.04 & [89] & {$[$ Emim $] \mathrm{PF}_{6}$} & 0.44 & [91] \\
\hline$[\mathrm{Emim}](\mathrm{EtO})_{2} \mathrm{PO}_{2}$ & & & & & & 1.00 & [89] & {$[\mathrm{Bmim}] \mathrm{CH}_{3} \mathrm{SO}_{3}$} & 0.85 & [91] \\
\hline$[\mathrm{Emim}] \mathrm{Cl}$ & & 89 & 285 & & & & [92] & {$[\mathrm{Bmim}] \mathrm{Br}$} & 0.87 & [91] \\
\hline$[$ Emim $] \mathrm{H}_{2} \mathrm{PO}_{2}$ & & 17 & 260 & 0.97 & 0.52 & 1.09 & [93] & & & \\
\hline$[\mathrm{Amim}](\mathrm{MeO}) \mathrm{HPO}_{2}$ & 123 & & 265 & 0.99 & 0.51 & 1.06 & [93] & & & \\
\hline$\left[\right.$ Prmim] $(\mathrm{MeO}) \mathrm{HPO}_{2}$ & 219 & & 277 & 1.00 & 0.54 & 1.02 & [93] & & & \\
\hline$[\mathrm{Bmim}](\mathrm{MeO}) \mathrm{HPO}_{2}$ & 287 & & 277 & 1.02 & 0.52 & 1.01 & [93] & & & \\
\hline [Emim]OAc 6,7 & 162 & & & 0.95 & 0.40 & 1.09 & {$[94,95]$} & & & \\
\hline
\end{tabular}

1-Allyl-3-methylimidazolium chloride, $[\mathrm{Amim}] \mathrm{Cl}_{\text {; }}$

Ethyl-3-methylimidazolium formate, $[\mathrm{Emim}] \mathrm{HCO}_{2}$;

1-Propyl-3-methylimidazolium formate, $[$ Prmim $] \mathrm{HCO}_{2}$;

1-Allyl-3-methylimidazolium formate, $[\mathrm{Amim}] \mathrm{HCO}_{2}$

1-Butyl-3-methylimidazolium acetate, [Bmim] $\mathrm{OAc}$

1-Butyl-3-methylimidazolium chloride, [Bmim]Cl;

1-Butyl-3-methylimidazolium formate, [Bmim] $\mathrm{HCO}_{2}$;

1-Ethyl-3-methylimidazolium dimethylphosphate, [Emim] $(\mathrm{MeO})_{2} \mathrm{PO}_{2}$ :

1-Ethyl-3-methylimidazolium methylphosphonate, [Emim] $(\mathrm{MeO}) \mathrm{HPO}_{2}$

1-Ethyl-3-methylimidazolium methyl methylphosphonate, [Emim] $(\mathrm{MeO}) \mathrm{MePO}_{2}$;

1-Ethyl-3-methylimidazolium diethylphosphate, [Emim] $(\mathrm{EtO})_{2} \mathrm{PO}_{2}$;

1-Ethyl-3-methylimidazolium chloride, [Emim]Cl;

1-Ethyl-3-methylimidazolium dyhidrogenphosphate, [Emim $] \mathrm{H}_{2} \mathrm{PO}_{2}$;

1-Allyl-3-methylimidazolium methylphosphonate, [Amim] $(\mathrm{MeO}) \mathrm{HPO}_{2}$;

1-Propyl-3-methylimidazolium methylphosphonate, [Prmim] $(\mathrm{MeO}) \mathrm{HPO}_{2}$

1-Butyl-3-methylimidazolium methylphosphonate, [Bmim] $(\mathrm{MeO}) \mathrm{HPO}_{2}$;

1-Ethyl-3-methylimidazolium acetate, [Emim]OAc;

2 Solubility conditions: $2-8 \mathrm{wt} \%$ of cellulose in $\mathrm{IL}$, temperature of dissolution from $100{ }^{\circ} \mathrm{C}$ to $130^{\circ} \mathrm{C}$;

3 Kamlet-Taft parameters values measured at $25^{\circ} \mathrm{C}$ using a single set of dyes: Reichardt's dye, 4-nitroaniline and $N, N$-diethyl-4-nitroaniline;

$\beta$ value obtained using the 3-(4-amino-3-methylphenyl)-7-phenyl-benzo-[1,2-b:4,5- $\left.b^{\prime}\right]$-difuran-2,6-di-one dye;

Solubility conditions: $5 \mathrm{wt} \%$ of cellulose in IL, temperature of dissolution $50{ }^{\circ} \mathrm{C}$;

Kamlet-Taft parameters measured using Reichardt's dye 2,6-Diphenyl-4-(2,4,6-triphenyl- $N$-pyridino) phenolate:

Viscosity measured at $20^{\circ} \mathrm{C}$.

The $\beta$ parameter is considered an excellent predictor of lignocellulosic biomass pretreatment efficacy [96]. Cellulose dissolving ILs present $\beta$ values between 0.83 and 1.09, while non-cellulose dissolving IL $\beta$ values range from 0.21 to 0.87 , as shown in Table 1. Strong hydrogen-bonding basicity alkyl methylimidazolium-based ILs can be designed using various anions: $\mathrm{Ac},(\mathrm{MeO}) \mathrm{MePO}_{2}$, $(\mathrm{MeO}) \mathrm{HPO}_{2}, \mathrm{HCO}_{2},(\mathrm{MeO})_{2} \mathrm{PO}_{2}, \mathrm{Cl}, \mathrm{H}_{2} \mathrm{PO}_{2}$. Furthermore, the dipolarity/polarizability studied [97] as a function of cation-anion interaction strength indicates an increase with stronger ion pairing effect i.e., the resulting cation effect on $\pi^{*}$ is different with weakly coordinating anion compared to the strongly coordinating anion (e.g., chloride). It is expected that 1-alkyl-3-methylimidazolium cations show larger values of $\pi^{*}$ [98], even when compared with different cations sharing the same anion, such that imidazolium $>$ pyridinium $>$ pyrrolidinium [99].

\subsection{Viscosity of Concentrated Cellulose Solutions in ILs}

The viscosity of ILs depends on their molecular structure and interactions between ions: electrostatic, Van der Waals, and hydrogen bonds [100]. To obtain low viscosity ILs, it is necessary to select asymmetrical cations and anions (irregular packing) or increase their size. Increasing the distance between the cation and anion, the ionic interaction become weaker [101]. In ILs having a common anion and a similar alkyl chain length on the cation, the viscosity increases when increasing the cation size, in the following order: imidazolium < pyridinium < pyrrolidinium [102]. In general, viscosities increase with the increasing number and length of alkyl substituents on the cation. Pyridinium salts are, in general, more viscous than the equivalent imidazolium compounds [103], as shown in Table 2. 
Table 2. Viscosity $(\eta)$, density $(\varrho)$, and water content (wt \%) of ILs.

\begin{tabular}{|c|c|c|c|c|c|c|}
\hline & $\mathrm{IL}^{1}$ & $\mathrm{~T}\left({ }^{\circ} \mathrm{C}\right)$ & $\eta(\mathrm{mPa} \cdot \mathrm{s})$ & $\varrho\left(\mathrm{kg} / \mathrm{m}^{3}\right)$ & Water $(w t \%)^{2}$ & Ref. \\
\hline \multicolumn{7}{|c|}{ Methylimidazolium } \\
\hline & $\mathrm{m}] \mathrm{OAc}$ & 20 & 646 & & 1.100 & [103] \\
\hline & ENG $41 \mathrm{M}$ & 20 & 1676 & & 0.083 & [103] \\
\hline & $\mathrm{m}] \mathrm{OAc}$ & 20 & 429 & 1055 & 0.085 & [104] \\
\hline$[\mathrm{Bn}$ & $\mathrm{m}] \mathrm{Cl}$ & 25 & & 1080 & 0.220 & [105] \\
\hline [Ar & $\mathrm{im}] \mathrm{Cl}$ & 25 & 821 & 1166 & 0.180 & [106] \\
\hline [En & $\mathrm{m}] \mathrm{OAc}$ & 20 & 202 & 1102 & 0.124 & [107] \\
\hline & $\mathrm{m}](\mathrm{MeO}) \mathrm{HPO}_{2}$ & 20 & 286 & 1212 & 0.078 & [107] \\
\hline & $\mathrm{m}] \mathrm{CH}_{3} \mathrm{SO}_{3}$ & 20 & 232 & 1246 & 0.029 & [107] \\
\hline & $\mathrm{m}] \mathrm{CF}_{3} \mathrm{SO}_{3}$ & 20 & 52 & 1390 & 0.002 & [107] \\
\hline$[\mathrm{En}$ & m]Tos & 30 & 1417 & 1223 & 0.056 & [107] \\
\hline & $\mathrm{m}](\mathrm{MeO})_{2} \mathrm{PO}_{2}$ & 30 & 193 & 1214 & 0.014 & [107] \\
\hline & $\mathrm{m}] \mathrm{EtSO}_{4}$ & 20 & 125 & 1240 & 0.105 & [108] \\
\hline \multicolumn{7}{|c|}{ Pyridinium } \\
\hline$[\mathrm{En}$ & py]EtSO 4 & 20 & 204 & & 0.026 & [103] \\
\hline & $\mathrm{EtSO}_{4}$ & 20 & 183 & & 0.068 & [103] \\
\hline & $\mathrm{y}] \mathrm{EtSO}_{4}$ & 25 & 325 & 1220 & $<0.08$ & [109] \\
\hline & $\mathrm{CH}_{3} \mathrm{SO}_{4}$ & 25 & 116 & 1345 & $<0.06$ & [109] \\
\hline & $\mathrm{py} \mathrm{CH}_{3} \mathrm{SO}_{4}$ & 25 & 129 & 1302 & $<0.06$ & [109] \\
\hline & py]CH $\mathrm{CH}_{3} \mathrm{SO}_{4}$ & 25 & 456 & 1285 & $<0.08$ & [109] \\
\hline \multicolumn{7}{|c|}{ Pyrrolidinium } \\
\hline & oyr]OAc & 25 & 107 & 1021 & 0.070 & [104] \\
\hline & $\mathrm{yr}] \mathrm{CF}_{3} \mathrm{SO}_{3}$ & 20 & 222 & 1256 & 0.072 & [100] \\
\hline & pyr](BtO) $\mathrm{HPO}_{2}$ & 25 & 321 & 1082 & 0.025 & [110] \\
\hline & $\mathrm{yyr}](\mathrm{EtO}) \mathrm{HPO}_{2}$ & 25 & 320 & 1123 & 0.021 & [110] \\
\hline \multicolumn{7}{|c|}{ Butyl-3-methylimidazolium acetate, [Bmim]OAc; } \\
\hline 2 & $\begin{array}{l}\text { 1-Butyl-3-meth } \\
\text { 1-Butyl-3-meth } \\
\text { 1-Allyl-3-methy } \\
\text { 1-Ethyl-3-methy } \\
\text { 1-Ethyl-3-methy } \\
\text { 1-Ethyl-3-methy } \\
\text { 1-Ethyl-3-methy } \\
\text { 1-Ethyl-3-methy } \\
\text { 1-Ethyl-3-methy } \\
\text { 1-Ethyl-3-methy } \\
\text { 1-Ethyl-3-methy } \\
\text { 1-Ethylpyridini } \\
\text { 1,2-Diethylpyri } \\
\text { 1-methylpyridi } \\
\text { 2-ethyl-1-methy } \\
\text { 1-Butyl-1-methy } \\
\text { 1-Butyl-1-methy } \\
\text { 1-Butyl-1-methy } \\
\text { 1-Ethyl-1-methy } \\
\text { Water content }\end{array}$ & $\begin{array}{l}\text { limidazo } \\
\text { imidazo } \\
\text { imidazo } \\
\text { imidazo } \\
\text { imidazo } \\
\text { imidazo } \\
\text { imidazo } \\
\text { imidazo } \\
\text { imidazo } \\
\text { imidazo } \\
\text { pyridini } \\
\text { m ethyls } \\
\text { inium et } \\
\text { ium met } \\
\text { pyridini } \\
\text { lpyrrolid } \\
\text { lpyrrolid } \\
\text { pyrrolid } \\
\text { pyrrolid } \\
\text { eight fra }\end{array}$ & $\begin{array}{l}\text { 2-methoxyet } \\
\text { oride, [Bmir } \\
\text { oride, [Amin } \\
\text { tate, [Emim } \\
\text { thylphosph } \\
\text { thanesulfon } \\
\text { fluorometha } \\
\text { ylate, [Emin } \\
\text { nethylphosp } \\
\text { ylsulfate, [E } \\
\text { lsulfate, [En } \\
\text { Epy]EtSO } 4 \\
\text { te, [EEpy]Et } \\
\text { te, [Mpy]CH } \\
\text { tylsulfate, [E } \\
\text { cetate, [Bmp } \\
\text { ifluorometh } \\
\text { utylphospho } \\
\text { hylphospho } \\
\text { rcentage) of }\end{array}$ & $\begin{array}{l}\text { Emim] }(\mathrm{Me} \\
\text { nim] } \mathrm{CH}_{3} \mathrm{SC} \\
\text { onate, }[\mathrm{Emi} \\
\text { Emim] }(\mathrm{MeC} \\
\mathrm{tSO}_{4} \\
\mathrm{O}_{4}\end{array}$ & $\begin{array}{l}\mathrm{CF}_{3} \mathrm{SO}_{3} ; \\
\mathrm{O}_{2} \\
\mathrm{O}_{2} ; \\
\text { ments of viscosit }\end{array}$ & ensity. \\
\hline
\end{tabular}

From the alkylmethylimidazolium-based ILs viscosities, it is clear that chloride anion increases the value of that property, as reported in literature [111]. In addition, even the presence of very low concentrations of chloride as an impurity in non-chloride-based alkylimidazolium ILs increases the viscosity. Seddon et al. [111] related this issue to an increase in the cohesive forces via hydrogen bonding between the chloride and the protons of the imidazolium ring. In the same work, it was also concluded that the presence of water and other molecular co-solvents reduces the viscosity of ILs. For example, viscosities of binary mixtures [112] of water $+[\mathrm{Amim}] \mathrm{Cl}$ and ethanol $+[\mathrm{Amim}] \mathrm{Cl}$ 
measured in the range of $20-60{ }^{\circ} \mathrm{C}$ with water molar fraction up to 0.8 and ethanol of 0.55 are up $85 \%$ lower than the viscosity of the pure IL.

While the addition of molecular solvents to an IL decreases the solution viscosity, the addition of cellulose increases drastically the viscosity of the mixture. Concentrated cellulose/IL solutions show non-Newtonian behavior. The Newtonian behavior is lost progressively with increasing polymer concentration [113] explained by the increase of interactions between polymer chains and restriction of the motion of individual chains. Concentrated cellulose solutions (cellulose mass concentrations between 4 and $12 \%$ ) usually require dissolution temperature of $100{ }^{\circ} \mathrm{C}[114,115]$. The zero shear viscosity of concentrated cellulose solutions in [Amim]Cl, in the range of 10 to $25 \mathrm{wt} \%$ at $100{ }^{\circ} \mathrm{C}$, presents values between 2209 and 125,700 Pa.s [113]. These values represent a challenge for cellulose processing with ILs with high viscosity. The viscosities of mixtures IL + cellulose were compared at $85^{\circ} \mathrm{C}$ by Kosan [116], and were found to increase in the following order: [Emim]OAc (2281 Pa.s) < $[\mathrm{Bmim}] \mathrm{OAc}(9690 \mathrm{~Pa} \cdot \mathrm{s})<[\mathrm{Emim}] \mathrm{Cl}(24,900 \mathrm{~Pa} \cdot \mathrm{s})<[\mathrm{Bmim}] \mathrm{Cl}(47,540 \mathrm{~Pa} \cdot \mathrm{s})<[\mathrm{Bdmim}] \mathrm{Cl}(188,400 \mathrm{~Pa} \cdot \mathrm{s})$, with cellulose concentrations between $12.8 \%$ and $15.8 \%$. The viscosity of solutions of 4 and $8 \mathrm{wt} \%$ cellulose fibers $\left(\mathrm{DP}=650\right.$ ) in [Amim] $\mathrm{Cl}$ at $80{ }^{\circ} \mathrm{C}$ reported by Zhang et al. [59] was respectively 110 and $1480 \mathrm{~Pa} \cdot \mathrm{s}$. In order to improve the processability of cellulose, a co-solvent can be added to reduce the viscosity of the solution, but the co-solvent must be chosen in order that it does not reduce the solubility of cellulose in water. The most frequent co-solvent used in cellulose processing is DMSO. The maximal amount of cellulose dissolved in [Emim]OAc + $10 \mathrm{wt} \%$ DMSO is five times higher than at [Emim]OAc $+10 \mathrm{wt} \%$ water [117]. The cellulose intrinsic viscosity of the solution does not depend on DMSO content, but the addition of water higher than 10-15\% in cellulose/[Emim]OAc solution leads to cellulose coagulation [117]. Although, cellulose/IL/DMSO solutions behave as Newtonian fluids at very low cellulose concentration $(<0.80 \mathrm{wt} \%)$, the solution viscosity increases with cellulose concentration and exhibits a shear-thinning behavior at higher shear rates [118]. Additionally, shear thinning behavior can be detected, as well with dimethylacetamide (DMAc) and dimethylformamide (DMF), at high fractions of IL [119]. As an alternative to water or organic solvents, viscosity reduction can be provided by carbon dioxide $\left(\mathrm{CO}_{2}\right)$ [120]. Using $\mathrm{CO}_{2}$ as a co-solvent has the advantages of being cheap, non-toxic, and can be easily separated of the IL when decreasing the pressure. In biphasic mixtures of IL- $\mathrm{CO}_{2}$ at moderate or high pressure, $\mathrm{CO}_{2}$ can dissolve significantly into the IL-rich liquid phase, up to concentrations round $30-40 \%$ in mol [121] in the case of imidazolium chloride ILs. $\mathrm{CO}_{2}$ is not causing the precipitation of cellulose, except in ILs with acetate anion, in which a reversible carboxylate reaction occurs that cause cellulose precipitation [122,123].

To the best of our knowledge, only a few viscosity data of mixtures $\mathrm{CO}_{2}+\mathrm{IL}$ can be found in literature [124-126] for non-cellulose dissolving ILs, and for the mixture $\mathrm{CO}_{2}+$ [Amim] $\mathrm{Cl}$ [127]. In general, the reduction in viscosity is between $85 \%$ and $45 \%$ at moderate pressures of 10-12 MPa, but with molar fractions as low as $10 \%$ of $\mathrm{CO}_{2}$, viscosity can decrease $30-40 \%$ with respect to the viscosity of the pure IL. In all cases, the effect in viscosity reduction with $\mathrm{CO}_{2}$ is more important at lower temperatures, where both viscosities and $\mathrm{CO}_{2}$ solubilities are higher.

The effect of $\mathrm{CO}_{2}$ in IL + cellulose mixtures was only studied by Iguchi et al. [128], with and acetate anion IL, using low concentrations of cellulose to avoid its precipitation with $\mathrm{CO}_{2}$. At $4 \mathrm{MPa}$ and $39{ }^{\circ} \mathrm{C}$, viscosity can be reduced of $1.2 \mathrm{wt} \%$ cellulose $+[\mathrm{Bmim}] \mathrm{OAc}$ solution by about $80 \%$.

\subsection{Water Effect on the Anion Interaction with Cellulose}

The presence of water or alcohol in an IL decreases the solubility of cellulose, so they can cause cellulose precipitation from IL solutions. Nevertheless, in the case of water, it can be a serious challenge for the cellulose processing in ILs, because even partially water-immiscible ILs are hygroscopic, and are able to absorb up to $1 \%$, by weight, of water from the environment [129]. Absorbed water interacts with the anions, and these interactions can cause changes in the structure of water [130]. Cammarata et al. [131] showed that for low coordinating anion (low basicity), water is associated with the anion of the ILs via hydrogen bonding, instead of being self-associated. In those cases, 
the concentrations of the dissolved water are typically in the range of $0.2 \pm 1.0 \mathrm{~mol} / \mathrm{L}$. In ILs with strongly coordinating anion (highly basic, that is, those able to dissolve cellulose), water molecules can self-associate, being able to dissolve much higher water amounts that may exceed $1.0 \mathrm{~mol} / \mathrm{L}$.

Adding water to the solution cellulose/IL means that the water-anion interactions saturate the hydrogen-bonding ability of the anions, allowing the water molecules to form hydrogen bonds with cellulose [132], meanwhile, the cations are maintained in a second solvation shell of cellulose, due to strong interactions with anions. Computer simulations [133] using 1-alkyl-3-methylimidazolium cations ( $\mathrm{n}=1,2,3,4,5)$ paired with chloride, acetate, or dimethylphosphate, showed that water crowds the hydrogen-accepting sites of the anions, preventing interactions with cellulose.

\section{Industrial Cellulose Derivative Production Methods}

Fibers are divided into two groups: natural fibers and chemical fibers (man-made fibers). Natural materials are dissolved to make cellulose fibers, such as wood pulp or cellulose. The market is focusing on using cellulose fibers through renewable sources [134]. Most fibers made from cellulose derivatives are produced by replacing the hydrogen atoms of hydroxyl groups in the AGUs of cellulose with alkyl or substituted alkyl groups [135]. Cellulose derivatives can be cellulose esters and ethers. They are generally synthesized by esterification of cellulose with inorganic or organic acids, or by etherification or Michael addition in heterogeneous or homogeneous media, respectively [135]. Cellulose derivatives production mechanism using ILs is schematized in Figure 3.
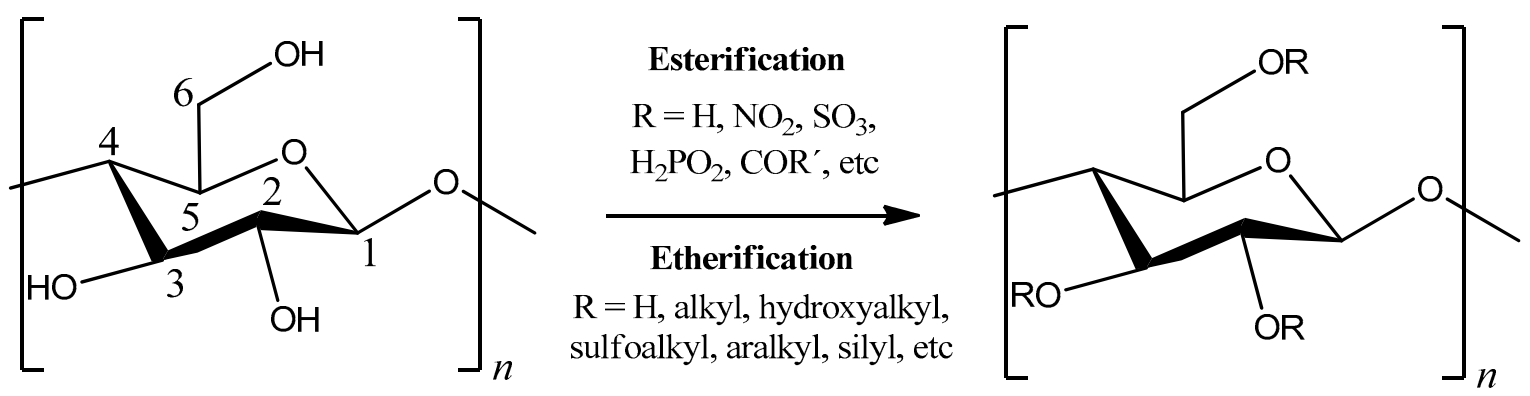

Figure 3. Synthesis of cellulose esters and ethers. Reprinted with permission from [135]. Copyright 2013 John Wiley and Sons.

Depending on the number of hydroxyl groups substituted, cellulose derivatives may have low or high degree of substitution (DS). The degree of substitution is a measure of the average number of hydroxyl groups on each AGU unit which are derivatized by substituent groups. As each AGU has three hydroxyl groups available for substitution, the maximum possible DS is 3 . Cellulose contains $31.48 \%$ by weight of hydroxyl groups (one primary and two secondary per AGU) and the reactivity of these hydroxyl groups varies according to the reaction medium in which functionalization is done [136].

Since 1944, cellulose esters have been produced [137] by a simple heterogeneous process consisting of pouring a mixture containing the acetylation agent into water, filtering, washing, and drying. The polymers have been produced in different shapes: films, fibers, plastics, and coating applications. Several organic cellulose esters have been used in commercial products or in pharmaceutical investigations, such as cellulose acetate (CA), cellulose acetate phthalate (CAP), cellulose acetate butyrate (CAB), and cellulose esters based on inorganic acids, e.g., cellulose nitrate, and silylated celluloses, such as trimethylcellulose and others [138].

Commercially marketed cellulose acetates have versatile applications [139]. Besides their traditional applications as additives in the food industry, in coatings, printing, cosmetic, textile, and in the pharmaceuticals industry, new cellulose derivatives have also been investigated for their applications, such as drug delivery systems [140], in chiral separation and recognition [141], as 
photoactive materials [142], as antioxidant agents [143], in memory of electronic devices [144], and graft copolymers [145].

The properties of cellulose ethers important for their commercialization are determined by their molecular weights, chemical structure, and distribution of the substituent groups, degree of substitution, and molar substitution [146]. Examples of mostly used cellulose ethers are methyl cellulose (MC), ethyl cellulose (EC), hydroxyethyl cellulose (HEC), hydroxypropyl cellulose (HPC), hydroxypropylmethyl cellulose (HPMC), and carboxymethyl cellulose (CMC). Cellulose ethers act as thickeners, binders, film formers, and water retention agents in construction applications, although they function also as suspension aids, surfactants, lubricants, protective colloids, and emulsifiers [147]. HPC and HEC, in particular, have been investigated for production of antibiotics [148].

Natural cellulose has highly crystalline regions, in which a highly branched hydrogen bonding network makes it insoluble in water and many organic solvents. This explains why standard commercial methods for producing cellulose derivatives begin as heterogeneous reactions, followed, in the case of esters, by a subsequent back-hydrolysis reaction [149]. In the case of cellulose ethers, an activation of the cellulose prior to the heterogeneous etherification is required, and the produced cellulose ethers exhibit non-uniform mixtures [150]. Cellulose must be activated to break its crystallinity before etherification to obtain a soluble product. A common method of cellulose activation is to mercerize it with $\mathrm{NaOH}$ [151].

Cellulose derivatives synthesized in homogeneous reaction media could have different properties from those of cellulose derivatives synthesized in heterogeneous media with similar chemical compositions. When the reactions proceed in homogeneous solutions, the regioselectivity depends on the reactivity differences among the free hydroxyl groups on the cellulose molecules [152], not by their accessibility [153].

The most prominent example for the utilization of ILs as cellulose solvent are the Ioncell-F fibers. The process to make lyocell [154] fibers is a solvent spinning process (dry-jet wet spinning). The cellulose is directly dissolved in the solvent NMMO/water or ILs (Ioncell-F fibers) such as [Bmim]Cl, [Bmim]OAc, [Emim]Cl, [Emim]OAc, and [DBNH]OAc [155], spun through an air gap and precipitated in water. Thus, this fiber is composed of cellulose because it has not suffered substitution reactions. The Table 3 compares the structure and mechanical properties of the viscose fiber [156] to cellulose fibers prepared from NMMO and ILs [157]. Viscose fiber is a cellulose fiber made from wood pulp, however, has several drawbacks due to the use of highly toxic carbon disulfide $\left(\mathrm{CS}_{2}\right)$ and precipitate formation, owing to chemical degradation of polysaccharides [158].

Table 3. Comparison of mechanical properties of regenerated cellulose fibers from viscose process [156] to NMMO and ILs [157].

\begin{tabular}{|c|c|c|c|c|c|}
\hline Fiber/Solvent ${ }^{1}$ & $\begin{array}{l}\text { Cross-Section } \\
\text { Shape }\end{array}$ & $\begin{array}{l}\text { Tenacity Cond. } \\
\text { (cN/tex) }\end{array}$ & $\begin{array}{l}\text { Elongation } \\
\text { Cond. }(\%)\end{array}$ & $\begin{array}{l}\text { Commercial/Experimental } \\
\text { Fiber }\end{array}$ & Ref. \\
\hline Viscose & Lobate & 22 & & com. & [156] \\
\hline NMMO & Round & 40.2 & 13.0 & com. & [157] \\
\hline$[$ Emim]Cl & Round & 43.0 & 9.6 & exp. & [157] \\
\hline$[\mathrm{Bmim}] \mathrm{Cl}$ & Round & 50.1 & 9.3 & exp. & [157] \\
\hline [Emim]OAc & Round & 44.7 & 10.4 & exp. & [157] \\
\hline \multicolumn{6}{|c|}{$1 \quad \mathrm{~N}$-methylmorpholine- $\mathrm{N}$-oxide, $\mathrm{NMMO}$} \\
\hline \multicolumn{6}{|c|}{$\begin{array}{l}\text { Ethyl-3-methylimidazolium chloride, }[\mathrm{Emim}] \mathrm{Cl} \text {; } \\
\text { 1-Butyl-3-methylimidazolium chloride, }[\mathrm{Bmim}] \mathrm{Cl} \text {; } \\
\text { 1-Ethyl-3-methylimidazolium acetate, }[\mathrm{Emim}] \mathrm{OAc} \text {. }\end{array}$} \\
\hline
\end{tabular}


Fiber characterization is normally done by measuring the tenacity and the elongation at break. Furthermore, titer, modulus and cross-section can be determined [157]. The level of stretching determines the tenacity and elongation level. A high degree of stretching results in a relatively tear-resistant and low strain fiber. A higher elastic modulus means a higher resistance of the fiber against deformation. The same cross-section can be obtained for different solvent systems assuming the use of similar spinnerets. NMMO and ILs present fiber properties in the same range (Table 3) and the same cross-section (round). Higher tenacity, crystallinity, and molecular weight can be obtained using the lyocell process [159]. Degradation during the lyocell process should be less than $10 \%$, thus similar fiber properties of lyocell fibers spun from ILs compared to NMMO suggest similar solution structures of cellulose [159]. Additionally, the mechanical properties of the regenerated fibers, such as tensile strength and elongation at break, can be strongly dependent on the DP of the original cellulose [160].

Despite many advantages, the lyocell process still produces fibers with severe fibrillation. Fibrillation is the peeling away of fibrils of the fiber surface by applying mechanical stress to fibers which are swollen in water [161]. This is undesired, especially in the processing from fiber to fabric. Methods for fibrillation reduction have been published [162-164]. The use of NMMO, which is a thermally unstable solvent, could lead to uncontrolled thermal degradation. From the thermodynamic point of view, the state of a thermal explosion is reached that requires a major investment in safety technology [165]. Additionally, the use of high melting point alkylmethylimidazolium based ILs shows spinning dopes containing high cellulose concentration (e.g., $16.5 \mathrm{wt} \%$ ), however, the decomposition and the viscosity remain a challenge [166]. A new cellulose spinning solvent, consisting of a superbase-based IL, [DBNH]OAc, was reported to present high dissolution power and a low viscosity [155], and to produce high tenacity fibers (over $50 \mathrm{cN} /$ tex).

It has been demonstrated that chemical modification of cellulose may be carried out under homogenous conditions using ILs in a commercial scale towards high-value cellulose derivatives, as published in a patents review [167]. The substitution reaction using ILs does not require an inorganic base in order to activate cellulose [168]. The performance of the homogeneous reaction in IL media presents a number of advantages, the main one being the existence of different options in introducing functional groups, and the better control of the DP and in the degree of substitution (DS). An overview over cellulose derivatives from ILs is reported [169]. The conditions of homogeneous substitution reactions in order to prepare cellulose derivatives are shown in Table 4. 
Table 4. Conditions of reaction media for the homogeneous esterification of cellulose and DS of the cellulose derivatives.

\begin{tabular}{|c|c|c|c|c|c|c|c|c|}
\hline $\mathrm{IL}^{1}$ & Co-Solvent ${ }^{2}$ & Catalyst & Base & $\mathbf{w t} \%^{3}$ & Reagent & Conditions ${ }^{4}$ & DS $^{5}$ & Ref. \\
\hline$[\mathrm{Amim}] \mathrm{Cl}$ & & DMAP & & 4 & Propionic anhydride, butyric anhydride & $\begin{array}{c}\text { 1:1-5:1; } \\
2-180 \mathrm{~min} \\
20-100{ }^{\circ} \mathrm{C}\end{array}$ & $\begin{array}{l}\text { Prop: } 0.89-2.89 \text {, But: } \\
0.91-2.76\end{array}$ & [168] \\
\hline [Amim]Cl & & & & 4 & $\begin{array}{l}\text { Propionic anhydride, acetic anhydride, butyric } \\
\text { anhydride }\end{array}$ & $\begin{array}{l}\text { 5:1,9:1, 13:1; } \\
\text { 60-300 min; } \\
80-100^{\circ} \mathrm{C}\end{array}$ & $\begin{array}{l}\text { Prop: } 0.93-2.46 \text {, But: } \\
0.86-2.07\end{array}$ & [170] \\
\hline$[\mathrm{Bmim}] \mathrm{Cl}$ & & & Py & 11 & Acetyl chloride & $\begin{array}{l}3: 1,5: 1,10: 1 ; \\
2 \mathrm{~h} ; 80^{\circ} \mathrm{C}\end{array}$ & Ac $<3.00$ & [171] \\
\hline$[\mathrm{Amim}] \mathrm{Cl}$ & & & $\mathrm{Py} / \mathrm{Et}_{3} \mathrm{~N}$ & 10 & Acetic anhydride, tosyl chloride & $\begin{array}{l}\text { 3:1, 8:1; } \\
48 \text { h, r.t. }\end{array}$ & Ac: 2.99 , Tos: 0.84 & [172] \\
\hline [Emim]OAc & & & IM & 3 & Tosyl chloride & $2: 1 ; 300 \mathrm{~min} ; 7^{\circ} \mathrm{C}$ & Tos: 0.55 & [173] \\
\hline$[\mathrm{Bmim}] \mathrm{Cl}$ & DMI & & Py, BIM & 11 & Tosyl chloride & $\begin{array}{c}1: 1-5: 1 ; \\
1-48 \mathrm{~h}: 25^{\circ} \mathrm{C}\end{array}$ & Tos: $1.14, \mathrm{Cl}: 0.16$ & [174] \\
\hline$[\mathrm{Bmim}] \mathrm{Cl}$ & & & Py & 11 & 2-furoyl chloride & $\begin{array}{l}1: 1,1: 1,5: 1 \\
0.5-17 \mathrm{~h} ; 65^{\circ} \mathrm{C}\end{array}$ & $0.46-3.00$ & [175] \\
\hline $\begin{array}{c}{[\mathrm{Bmim}] \mathrm{Cl}} \\
{[\mathrm{Emim}] \mathrm{Cl}} \\
{[\mathrm{Bdmim}] \mathrm{Cl}} \\
{[\mathrm{Admim}] \mathrm{Br}}\end{array}$ & & & Py & 11 & $\begin{array}{l}\text { Acetyl chloride } \\
\text { Phenyl isocyanate }\end{array}$ & $\begin{array}{c}\text { 3:1, 5:1, 10:1; } \\
15-120 \mathrm{~min} ; 80^{\circ} \mathrm{C}\end{array}$ & $\begin{array}{l}\text { Ac: } 2.81-3.0 \\
\text { Carb:0.26-3.0 }\end{array}$ & [176] \\
\hline$[\mathrm{Bmim}] \mathrm{Cl}$ & & & & 6 & $\begin{array}{l}\text { Phenyl isocyanate } \\
\text { Acetic anhydride }\end{array}$ & $\begin{array}{c}\text { 1:1-10:1; } \\
120-240 \mathrm{~min} ; 80{ }^{\circ} \mathrm{C}\end{array}$ & $\begin{array}{l}\text { Carb: } 0.29-3.0 \\
\text { Ac: } 0.69-3.0\end{array}$ & [177] \\
\hline$[\mathrm{Bmim}] \mathrm{Cl}$ & & & & 3 & Chloroacetyl chloride & $\begin{array}{l}\text { 60-300 min; } \\
30-50^{\circ} \mathrm{C}\end{array}$ & $0.33-1.87$ & [178] \\
\hline [Amim]Cl & DMF & & & 4 & 2-bromopropionyl bromide & $\begin{array}{c}5: 1 ; \\
480 \text { min; r.t. }\end{array}$ & 0.7 & [179] \\
\hline$[\mathrm{Amim}] \mathrm{Cl}$ & & & & 3-7 & $\begin{array}{l}\text { Benzoyl chloride, 4-toluoyl chloride, } \\
\text { 4-chlorobenzoyl chloride, } \\
\text { 4-nitrobenzoyl chloride }\end{array}$ & $\begin{array}{l}\text { 2:1-10:1; } \\
60-240 \mathrm{~min} ; \\
40-100^{\circ} \mathrm{C}\end{array}$ & $1-3.0$ & [180] \\
\hline$[\mathrm{Bmim}] \mathrm{Cl}$ & & & Py & $10-12$ & $\begin{array}{l}\text { Acetic anhydride, Propionic anhydride, Butyric } \\
\text { anhydride, } \\
\text { Pentanoic anhydride, Hexanoic anhydride }\end{array}$ & $\begin{array}{l}1: 1,3: 1,5: 1 ; \\
2 \mathrm{~h} ; 80^{\circ} \mathrm{C}\end{array}$ & $0.4-3.0$ & [181] \\
\hline $\begin{array}{l}{[\mathrm{Bmim}] \mathrm{Cl},} \\
{[\mathrm{Amim}] \mathrm{Cl},} \\
{[\mathrm{Emim}] \mathrm{OAc}}\end{array}$ & DMF & & & 11 & Sulfur trioxide, chlorosulfonic acid & $\begin{array}{c}1.3: 1-3: 1 ; \\
120-240 \mathrm{~min} ; 25^{\circ} \mathrm{C}\end{array}$ & $0.22-0.89$ & [182] \\
\hline$[\mathrm{Bmim}] \mathrm{Cl}$ & & & & 2.35 & Phthalic anhydride & $\begin{array}{c}\text { 2:1-10:1; } \\
20-120 \mathrm{~min} ; \\
85-105^{\circ} \mathrm{C} \\
1: 1-12: 1 ;\end{array}$ & $0.12-2.54$ & [183] \\
\hline$[\mathrm{Bmim}] \mathrm{Cl}$ & & & & 2 & Succinic anhydride & $\begin{array}{l}5-120 \mathrm{~min} ; \\
85-105^{\circ} \mathrm{C} \\
4: 1 ;\end{array}$ & $0.037-0.53$ & [184] \\
\hline$[\mathrm{Bmim}] \mathrm{Cl}$ & DMSO & NBS & & 2 & Succinic anhydride & $\begin{array}{l}30-240 \mathrm{~min} ; \\
90-120^{\circ} \mathrm{C}\end{array}$ & $0.24-2.31$ & [185] \\
\hline$[\mathrm{Bmim}] \mathrm{Cl}$ & & DMAP & & 2 & Succinic anhydride & $\begin{array}{l}4: 1 ; 30-120 \mathrm{~min} ; \\
\quad 60-110^{\circ} \mathrm{C}\end{array}$ & $0.24-2.34$ & [186] \\
\hline$[\mathrm{Bmim}] \mathrm{Cl}$ & & Iodine & & & Succinic anhydride & $\begin{array}{l}\text { 4:1; } 30-120 \mathrm{~min} ; \\
85-110^{\circ} \mathrm{C}\end{array}$ & $0.56-1.54$ & [187] \\
\hline $\begin{array}{c}{[\mathrm{Bmim}] \mathrm{Oac}} \\
{[\mathrm{Bmim}] \mathrm{Cl}} \\
{[\mathrm{Bmim}] \mathrm{OPr}}\end{array}$ & & & & & $\begin{array}{l}\text { Carboxylic anhydrides, carboxylic acid halides, } \\
\text { diketene, or acetoacetic acid esters }\end{array}$ & $<0.2$ (molar ratio) & $0.1-3.0$ & [188] \\
\hline
\end{tabular}


Table 4. Cont.

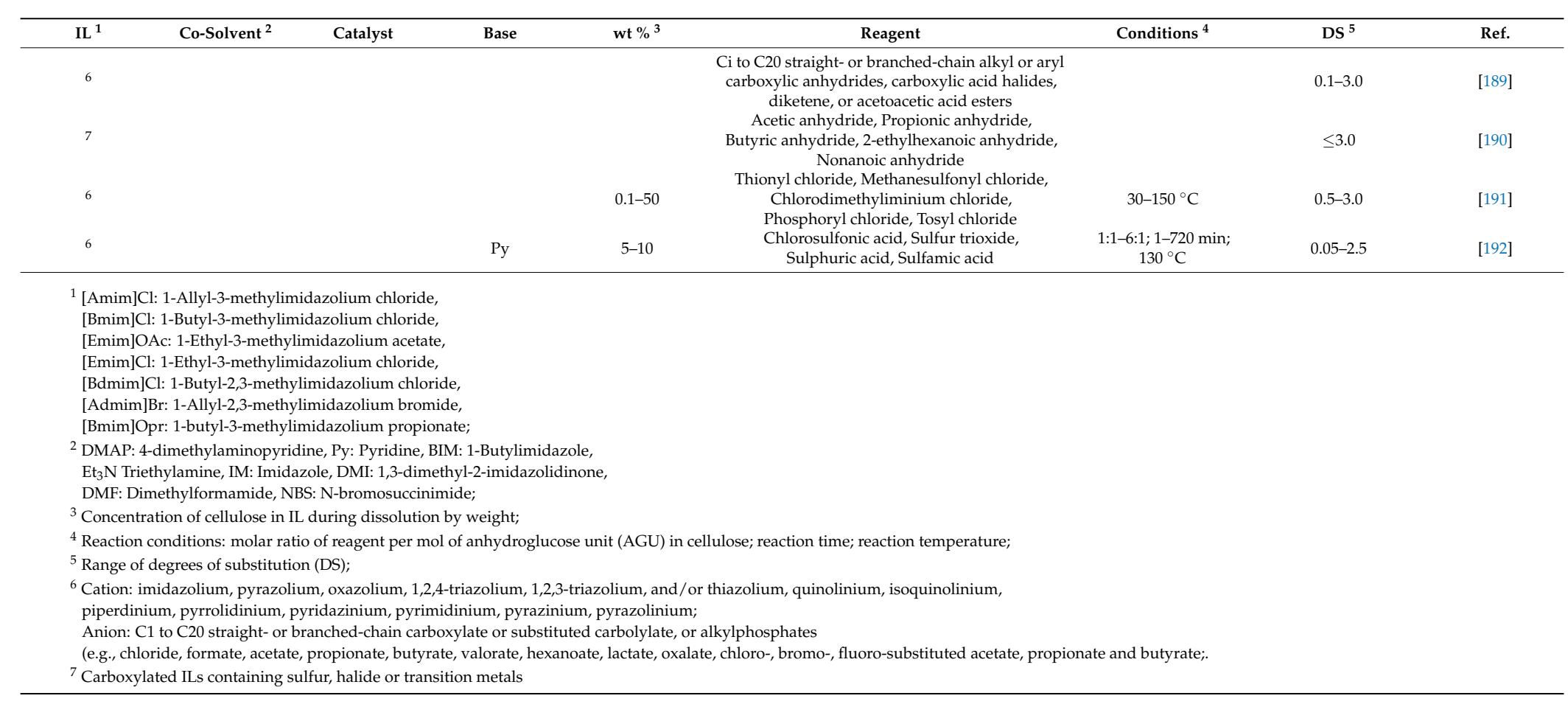




\subsection{Esterification}

Conversion of cellulose, dissolved in different ILs, with carboxylic acid chlorides or anhydrides is very efficient for the preparation of cellulose esters (Table 4). General synthesis route and molecular structure of cellulose esters homogeneously prepared in ILs were thoroughly reviewed elsewhere [193].

Cellulose acetate butyrate and cellulose acetate propionate can be prepared homogenously in [Amim] Cl from sugarcane bagasse [170]. The cellulose acetate content was affected by reaction temperature, reaction time, and molar ratio reagent/AGUs. With propionic anhydride, the DS obtained was between 0.89 and 2.89, and with butyric anhydride, from 0.91 to 2.76 . The most common methods for determination of DS include ${ }^{1} \mathrm{H}$ NMR, ${ }^{13} \mathrm{C}$ NMR in DMSO- $d_{6}, \mathrm{CDCl}_{3}$, or $\mathrm{D}_{2} \mathrm{O}$.

Heinze et al. [171] used [Bmim] $\mathrm{Cl}$ as reaction medium and synthesized cellulose acetates with high DS values in good yield ( $85.9 \%)$ within a short time ( $2 \mathrm{~h})$. DS was controlled by the amount of reagent added. The acetylating reagent acetic anhydride proved to be less effective than acetyl chloride. Cellulose fluorates can be synthesized with yields of $84.4 \%$ and $90.2 \%$ and with a DS range of $0.46-3.0$; thus, as $[\mathrm{Bmim}] \mathrm{Cl}$ is a very efficient medium for reaction, short reaction times and low amounts of acylation reagent are needed [175]. Cellulose benzoates with different moieties at the aromatic ring are prepared homogeneously in [Amim] $\mathrm{Cl}$ by conversion of cellulose with the corresponding benzoyl chlorides [180]. An excess of reagent of $5 \mathrm{~mol}$ per mol of AGU leads to completely substituted cellulose derivatives [181], such as cellulose pentanoates, cellulose hexanoates, with DS above 0.9 soluble in DMSO, and for DS of 2.3 soluble in DMSO, acetone, and chloroform $\left(\mathrm{CHCl}_{3}\right)$.

Cellulose sulfates were prepared through homogeneous conversion of cellulose with different sulfating reagents in $[\mathrm{Bmim}] \mathrm{Cl},[\mathrm{Amim}] \mathrm{Cl}$, and $[$ Emim] $\mathrm{OAc}$ and DMF as dipolar aprotic co-solvent [182]. The sulfation of cellulose in [Bmim] $\mathrm{Cl}$ proceeded in $30 \mathrm{~min}$ and the prolongation of the reaction time to $2 \mathrm{~h}$ did not change the DS values significantly. In contrast, after $24 \mathrm{~h}$, the DS of the products decreased from 0.83 to 0.66 , which is most likely due to acidic cleavage of the sulfate ester bond. The sulfation was investigated at $25^{\circ} \mathrm{C}$ and higher temperatures. The results show that sulfation at higher temperature does not give the desired DS, indicating decomposition of polymer chain. Production of cellulose sulfates with DS up to 2.5 was patented by Procter \& Gamble Company [192].

The p-toluenesulfonic acid esters of cellulose (cellulose tosylates) are versatile intermediates for the preparation of several cellulose derivatives. Homogeneous reaction yielding tosylated cellulose can be carried out in $[\mathrm{Amim}] \mathrm{Cl}$, and aspects such as the degree of tosylation, the reaction temperature and the base can be varied, e.g., trimethylamine is not fully mixed with [Amim] $\mathrm{Cl}$, however, pyridine works efficiently [172]. The homogeneous reaction produces a predominant conversion of primary hydroxyl groups at DS values up to $1[173,174]$. However, derivatization with tosyl chloride generates additional chloride as a second reaction product, thus, chlorination of cellulose occurs due to the presence of chloride ions in the reaction media (Figure 4). Additionally, a tosylated AGU can react as well with hydroxyl groups of the same or another cellulose chain, resulting in crosslinking, and thus, insoluble products. To prevent these side reactions, the temperature is kept at $8-10{ }^{\circ} \mathrm{C}$ [174].

Preparation of cellulose carbanilates with DS up to 3.0 could be prepared in [Bmim]Cl. The synthesis of cellulose carbanilates was carried out without any catalysts. Higher DS were accessible by increasing molar ratio and reaction time. Heinze [176] and Schlufter [177] showed that bacterial cellulose with DP $\sim 6500$ could be efficiently converted with phenyl isocyanate under homogeneous reaction conditions. Heinze and co-workers have investigated the acylation of cellulose in four types of ILs with lauroyl chloride, leading to cellulose laurates with DS ranging from 0.34 to 1.54 . The reaction was found to start homogeneously and then continue heterogeneously. DS values slightly increased with addition of a base such as pyridine and with shorter reaction time $(2 \mathrm{~h})$. Additionally, the acetates were soluble in DMSO, but not in acetone, and for DS higher than 2.85, were soluble in $\mathrm{CHCl}_{3}$. Schlufter compared DS of acetylated bacterial cellulose (BC) to the DS from the reaction with cellulose from plants (lower DP) and a lower reactivity was found. Highly substituted BC phenyl urethanes were soluble in DMSO, DMF, and in THF, depending on the DS. 


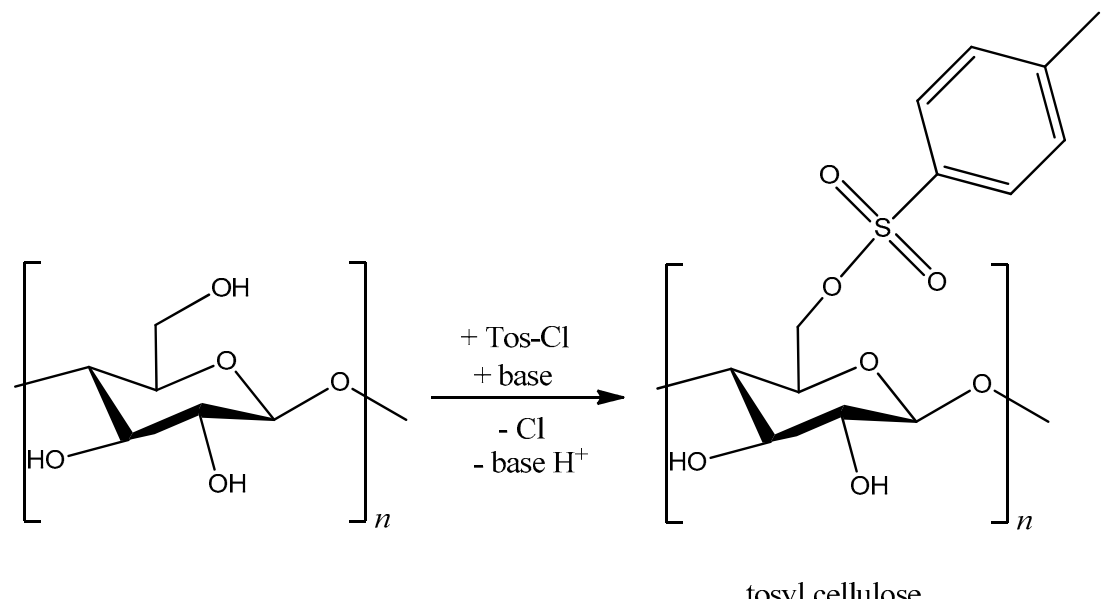

Figure 4. Tosylation of cellulose with tosyl chloride. Reprinted with permission from [174]. Copyright 2012 Elsevier.

Cellulose chloroacetates and bromoacetates were synthesized by acylation of cellulose with chloroacetyl chloride and 2-bromopropionyl bromide under mild conditions, in [ $\mathrm{Bmim}] \mathrm{Cl}$ and $[\mathrm{Amim}] \mathrm{Cl}$, respectively [178,179]. The cellulose acetates (macroinitiators) have been applied for subsequent preparation of methacrylate graft copolymers by atom transfer radical polymerization (ATRP).

[Bmim] $\mathrm{Cl}$ have been also applied as reaction media for the homogeneous preparation of dicarboxylic acid esters, such as cellulose phthalates [183] that can be prepared with DS ranging from 0.12 to 2.54 . DS increases with reaction temperature from 85 to $100{ }^{\circ} \mathrm{C}$, molar ratio of phthalic anhydride/AGU in cellulose from 2:1 to 10:1, and reaction time from 20 to $120 \mathrm{~min}$. Cellulose succinates are produced by succinoylation of cellulose using succinic anhydride and [Bmim]Cl (DS up to 2.18) [184], and with addition of catalysts: $N$-bromosuccinimide (DS up to 2.31) [185], 4-dimethylaminopyridine (DS up to 2.34) [186], and iodide (DS up to 1.54) [187].

Eastman Chemical Company have several patents that describe the homogeneous preparation of cellulose esters and mixed esters, and the recycling of the ILs by evaporation of precipitation agent as well as residues of the volatile acylation reagents [188-190,194]. In some of these inventions, the produced cellulose esters were used as protective and compensation films for liquid crystalline displays. A patent for chlorinating polysaccharides with DS up to 3 is also found in literature [191].

\subsection{Etherification}

In Millymaki and Aksela [195], there is an invention of a method for preparing cellulose ethers, where the derivatives have been divided into aliphatic cellulose ethers, comprising alkyl ethers, substituted alkyl ethers, hydroxyalkyl ethers, and mixed aliphatic ethers of cellulose. The second group comprises aryl and aralkyl ethers of cellulose, and the third group silyl ethers of cellulose. Table 5 presents some examples of etherification reactions of cellulose dissolved in different ILs.

Homogenous silylation of cellulose has been reported under mild conditions, within short reaction time at low temperature $\left(1 \mathrm{~h}, 80^{\circ} \mathrm{C}\right)$ and low excess of reagent [181]. Trimethylsilyl cellulose was obtained through reaction of cellulose dissolved in [Emim] OAc and [Emim] $\mathrm{Cl}$, with etherifying reagent hexamethyldisilazane (HMDS). [Emim] OAc is more efficient than [Emim] $\mathrm{Cl}$ in this reaction. It has been reported [196] that carboxylate and diethylphosphate counter-ions give better results than chloride. Furthermore, the solubility of HMDS in the IL increases with the increasing extent of $\mathrm{CH}_{\mathrm{x}}$ groups in the anion. Additionally, because of HMDS insolubility in the IL, trimethylsilyl cellulose precipitates, thus, the reaction starts homogeneously and ends heterogeneously. To keep it homogenous, a solvent is added (DMSO or DMAc). 
Table 5. Conditions of reaction media for the homogeneous etherification of cellulose and DS of the cellulose derivatives.

\begin{tabular}{|c|c|c|c|c|c|c|c|}
\hline $\mathrm{IL}^{1}$ & Co-Solvent $^{2}$ & Base & Cellulose (wt \%) ${ }^{3}$ & Reagent & Conditions ${ }^{4}$ & DS $^{5}$ & Ref. \\
\hline $\begin{array}{c}{[\text { Emim]OAc }} \\
{[\text { Emim] }] \mathrm{Cl}} \\
{[\text { Emim]Cl }}\end{array}$ & DMSO/DMA & & & Hexamethyldisilazane & $\begin{array}{l}3: 1,5: 1,8: 1 \\
1 \mathrm{~h} ; 80^{\circ} \mathrm{C}\end{array}$ & $1.6-2.9$ & [181] \\
\hline$[\mathrm{Emim}] \mathrm{Oac}$ & & & 10 & Hexamethyldisilazane & $16 \mathrm{~h}$ & $1.2-2.9$ & [196] \\
\hline $\begin{array}{l}\text { [Bmim]UAC } \\
\text { [Bmim]PrO }\end{array}$ & & & & & $80-120^{\circ} \mathrm{C}$ & & \\
\hline$[\mathrm{Bmim}] \mathrm{Cl}$ & & Py & 11 & Trityl chloride & $1-14 \mathrm{~h}, 100^{\circ} \mathrm{C}$ & $0.80-1.37$ & [197] \\
\hline [Emim]OAc & DMSO & & $4-11.5$ & $\begin{array}{l}\text { Propylene oxide, } \\
\text { ethylene oxide }\end{array}$ & $\begin{array}{l}5: 1-50: 1 ; \\
19 \mathrm{~h} ; 80^{\circ} \mathrm{C}\end{array}$ & $0.09-1.34$ & [200] \\
\hline $\begin{array}{l}{[\text { Emim]OAc, }} \\
{[\text { Bmim]Cl }}\end{array}$ & $\begin{array}{c}\mathrm{H}_{2} \mathrm{O}, \mathrm{DMSO} \\
\mathrm{DMF}, \mathrm{DME}, \\
\mathrm{CHCl}_{3}\end{array}$ & & & $\begin{array}{c}\text { Propylene oxide, } \\
\text { ethylene oxide, } \\
\text { 1-allyloxy-2,3-epoxypropane, } \\
\text { 2,3-epoxypropyl isopropyl, } \\
\text { etherepichlorohydrine, } \\
\text { 2,3-epoxypropyltrimethylammonium } \\
\text { chloride, phenylglycidyether, } \\
\text { 2,3-epoxypropyl isopropyl ether }\end{array}$ & $\begin{array}{c}5: 1,10: 1,30: 1 \\
3-72 \mathrm{~h} \\
21-100{ }^{\circ} \mathrm{C}\end{array}$ & $0.09-2.16^{6}$ & [201] \\
\hline \multicolumn{8}{|c|}{$\begin{array}{l}{ }^{1} \text { [Emim]OAc: 1-Ethyl-3-methylimidazolium acetate, } \\
\text { [Emim]Cl: 1-Ethyl-3-methylimidazolium chloride, } \\
\text { [Bmim]Cl: 1-Butyl-3-methylimidazolium chloride, } \\
\text { [Bmim]OAc: 1-Butyl-3-methylimidazolium acetate, } \\
\text { [Bmim]PrO: 1-butyl-3-methylimidazolium propionate, } \\
\text { [Amim]Cl: 1-Allyl-3-methylimidazolium chloride; }\end{array}$} \\
\hline \multicolumn{8}{|c|}{$\begin{array}{l}2 \text { DMSO: Dimethylsulfoxide, DMA: Dimethylacetamide, Py: Pyridine, BIM: 1-Butylimidazole, } \\
\text { DMF: Dimethylformamide, DME: Dimethoxyethane, } \mathrm{CHCl}_{3} \text { : Chloroform, }\end{array}$} \\
\hline \multicolumn{8}{|c|}{${ }^{3}$ Concentration of cellulose in IL during dissolution by weight; } \\
\hline \multicolumn{8}{|c|}{${ }^{4}$ Molar ratio of reagent per mol of anhydroglucose unit (AGU) in cellulose; reaction time; reaction temperature; } \\
\hline \multicolumn{8}{|c|}{${ }^{5}$ Range of degrees of substitution (DS); } \\
\hline${ }^{6}$ Molar su & stitution (MS). & & & & & & \\
\hline
\end{tabular}

Tritylation of cellulose with trityl chloride is an effective protecting group strategy for synthesizing regioselectively modified cellulose derivatives [199]. Homogeneous tritylation of cellulose in [Amim]Cl with trityl chloride $(\mathrm{TrCl})$ showed that DS can be influenced by the type of base used in the reaction (pyridine or 1-butylimidazole). The reaction with pyridine started heterogeneously, then changed to homogeneous finishing heterogeneous, and produced trityl cellulose with higher DS $\sim 1$. Despite the homogeneous reaction in the presence of 1-butylimidazole (BIM), the higher DS was 0.22. BIM is not considered suitable for tritylation of cellulose in ILs.

Köhler [200] reported the homogeneous hydroxyalkylation of cellulose without additional inorganic bases under completely homogeneous reaction conditions in [Emim] OAc at $80{ }^{\circ} \mathrm{C}$ for $19 \mathrm{~h}$. The reagents propylene oxide and ethylene oxide produced derivatives with a DS from 0.09 to 1.34. Addition of co-solvent (DMSO) to a higher concentrated solution of cellulose/IL changed the DS to higher value.

Patented [201] homogeneous reaction without addition of organic or inorganic bases with lower IL load prepares high DP (from 1000 to 6500) cellulose ethers. The cellulose ethers produced by this invention include 2-hydroxyethyl cellulose, 2-hydroxypropyl cellulose, 2-hydroxybutyl cellulose, 2-hydroxy-3-isopropoxy-propyl cellulose, 3-allyloxy-2-hydroxypropyl cellulose, 3-chloro-2-hydroxypropyl cellulose, (2-hydroxy-3-trimethylammoniumpropyl)-cellulose chloride, and 2-hydroxy-3-phenoxypropyl cellulose. These products are soluble in $\mathrm{H}_{2} \mathrm{O}$ and DMSO depending on the molar substitution (MS). MS values of hydroxyalkyl celluloses were determined by the method of Zeisel. Homogeneous synthesis of cellulose ethers [201] has been patented by Tylose $\mathrm{GmbH} \& \mathrm{Co}$. in ILs, such as [Bmim]Cl, [Emim]OAc, and co-solvents: DMSO, DMF, dimethoxyethane (DME), and $\mathrm{CHCl}_{3}$.

Patents of cellulose etherification process carried out under heterogeneous reactions conditions in [Bmim] $\mathrm{Cl}$ or [Emim] $\mathrm{Cl}$ are found in literature [202,203]. In contrast to the homogeneous process, the heterogeneous etherification method requires an activation of the cellulose prior to the etherification. 
The reaction mixture can progress as heterogeneous-homogeneous-heterogeneous. As an example, trimethylsilylcellulose can be produced by heterogeneous reaction of microcrystalline cellulose with [Bmim] $\mathrm{Cl}$ and silylating agent 1,1,1,3,3,3-hexamethyldisilazane (HMDS) (mol reagent/molAGU up to 5.6) at high temperature $\left(125^{\circ} \mathrm{C}\right)$, although with low DS up to 0.9 [202].

Commercially available hydroxyalkyl celluloses are prepared heterogeneously. This process requires activation of the cellulose which is a cause for higher costs and energy consumption. Additionally, because of the solid state of cellulose and intermediates, the product quality depends on the quality of the stirring and geometry of the reaction vessel [204]. In contrast, homogeneous production of cellulose derivatives allows the development of methods for synthesis of cellulose ethers without activation of cellulose, and high yields of products with new and better properties.

\section{Cellulose Precipitation}

Regeneration of cellulose from IL systems occurs by contact of the cellulose solution with a coagulation bath of protic polar solvents such as water or alcohols. Cellulose regeneration mechanisms for selected solvents have been reviewed elsewhere [205]. The yield of regenerated wood and the yield of recycled IL are affected by the choice of anti-solvent. Regeneration of $8 \mathrm{wt} \%$ solution of wood dissolved in [Amim] Cl yielded $>95 \%$ (weight percent from the original amount of wood) and practically all the IL could be recovered (under vacuum at $40^{\circ} \mathrm{C}$ ) using water as anti-solvent. Moreover, the yield of regenerated wood with water was reported to be higher than that of methanol at the same number of IL recycle uses (up to 3). Conventional precipitation can be achieved with anti-solvents, such as water (e.g., water concentration in IL > 20\% [117]), ethanol, methanol, and acetonitrile show high yields above $90 \%$. Precipitation with compressed $\mathrm{CO}_{2}$ has been reported as a "greener" alternative [206] Precipitation of cellulose dissolved in IL with acetate anion is produced by $\mathrm{CO}_{2}$ addition because the $\mathrm{CO}_{2}$ reacts with the acetate anion, forming another compound, a carboxylate zwitterion. With the formation of that compound, the bonds between cellulose and the acetate anion are broken, causing cellulose precipitation. The ILs can be regenerated by adding water in stoichiometric proportion, which destroys the zwitterion. The cellulose precipitated by this method presents a decrease of crystallinity and stability. At pressures between 6-18 MPa of $\mathrm{CO}_{2}, 60 \%$ of the cellulose dissolved in [Bmim]OAc is precipitated, resulting in relatively low yield compared to that of protic solvent. Despite the low yield, $\mathrm{CO}_{2}$ could be a sustainable method to regenerate cellulose from ILs.

The cellulose can be regenerated in the shape of powder, fibers, or films, but these last two forms are especially interesting. The fabrication of regenerated cellulose fiber/film involves two steps: dissolution of cellulose in IL to make the spinning dope, and extrusion of the spinning dope to form regenerated cellulose fiber and film. The influence of spinning conditions on cellulose crystallization that takes place during fiber/film precipitation with water, is of great importance in fiber and film processing, and has been studied in several works.

Sun and coworkers [207] studied the crystalline characteristics of regeneration of cellulose fiber, extrudate, and film from $6 \%$ cellulose $/[\mathrm{Bmim}] \mathrm{Cl}$ solution with different spinning conditions. The degree of crystallinity, crystal size, and crystallite orientation of the regenerated cellulose fiber and film, were evaluated using wide angle X-ray diffraction (WAXD).

WAXD data showed that cellulose regenerated from [Bmim]Cl solution was transformed from a cellulose I to cellulose II structure, and amorphous regions increased in the regenerated cellulose. Crystalline characteristics of regenerated cellulose are affected by the die shapes. A reduction of die diameter does not cause a significant change in fiber crystallinity, but results in an increase in crystallite size and crystal orientation factor. Additionally, fiber drawing speed was shown to be a main effect to improve fiber crystal orientation.

Airgap- and wet spinning of eucalypt dissolving grade pulp in [Emim]OAc and methylimidazole (MIM) was investigated by Olsson et al. [208]. Pure [Emim]OAc/cellulose solution was spun at $2.8 \mathrm{~m} \mathrm{~min}^{-1}$ through $150 \mu \mathrm{m}$ capillaries. For samples with co-solvent MIM, an $80 \mu \mathrm{m}$ holes spinneret was used due to lower viscosity. Coagulation took place in water, and fibers were drawn by rotating 
take-off rollers to desired extent. The fibers were then immersed in pure water for 1 week before drying at $105^{\circ} \mathrm{C}$ for $1 \mathrm{~h}$. The crystallinity of the fiber using only [Emim]OAc as solvent is lower than in fibers produced with co-solvent. However, fibers with higher tenacity cannot be achieved with high amount of co-solvent i.e., $\mathrm{x}_{\mathrm{IL}}=0.5$ in $15 \%$ pulp solutions.

Michud and coworkers [209] produced regenerated cellulose fibers by dry-jet spinning from cellulose/[DBNH]OAc solutions to study the influence of cellulose molecular structure on the spinnability and the mechanical properties of the resulting fibers. The solutions were extruded through a multi-hole spinneret ( 36 holes, diameter of $100 \mu \mathrm{m}$, and capillary length of $20 \mu \mathrm{m}$ ) via $1 \mathrm{~cm}$ air gap into a cold $\left(10-15^{\circ} \mathrm{C}\right)$ aqueous coagulation bath at a constant extrusion velocity of $16 \mathrm{~cm}^{3} / \mathrm{min}$. High spinnability with high stretching was found for a proportion of cellulose chain having DP $>2000$ larger than $20 \mathrm{wt} \%$ and DP $<100$ between 5 and $10 \mathrm{wt} \%$. The final properties of the fibers are directly affected by the draw of the fluid filaments in the air gap.

The effect of altering the coagulation medium during regeneration of cellulose dissolved in [Emim]OAc was also studied [210]. Cellulose solutions (4 wt \%) were coagulated in water, ethanol, and 1-propanol. For films coagulated in water, a higher degree of cellulose II was found, compared to the films coagulated in alcohols. The decreased preference of [Emim]OAc to diffuse into the coagulation bath could explain the lower conversion to cellulose II in alcohols.

Diffusion of [Bmim] Cl from cellulose filament during coagulation process was studied [211], and the factors affecting it: polymer concentration, concentration, and temperature of the coagulation bath. The diffusion rate of [Bmim] Cl decreased with increasing polymer content $(5,8,10$, and $12 \mathrm{wt} \%)$ in the spinning solution, and the initial concentration of [Bmim] Cl in the coagulation bath $(0-20 \mathrm{wt} \%)$, while the diffusion coefficients increased largely with the coagulation temperature becoming higher $\left(5-70{ }^{\circ} \mathrm{C}\right)$.

\section{Recycling of ILs after Cellulose Processing}

In general, synthesis of ILs is a polluting and energy intensive process that frequently involves the use of halide and/or sulfur intermediates, conventional organic solvents, or the use of metal oxide catalysts. Chlorinated organic compounds are undesired, due to the difficulties and safety issues in their disposal. For environmental and economic issues, it is important to recover and recycle ILs after the regeneration or derivatization of cellulose [212]. If these solvents are efficiently recycled, the overall waste production of the process will be decreased.

Methods used for recovery and recycling of ILs such as distillation, extraction, adsorption, induced phase separation, and membrane-based methods, were thoroughly reviewed elsewhere [213]. Thus, only a few considerations about this point will be treated here.

In cellulose processing, the most frequent impurities in ILs at the end of the process are heavy impurities due to the decomposition or incomplete precipitation of cellulose, and volatile impurities such as water or alcohols used to cause cellulose precipitation. Due to the negligible vapor pressure of ILs, volatile impurities can be removed from the IL mixture by evaporation without loss of the ILs. Nevertheless, this process can be energy intensive. Traditional methods like evaporation and extraction were applied to remove the impurities from [Emim]OAc, which had been previously used as medium for cellulose acetylation [214]. Impurities like ethyl acetate, $n$-propyl acetate, isopropyl acetate, and THF could be reduced from $40 \mathrm{wt} \%$ to $5 \mathrm{wt} \%$ within less than $1 \mathrm{~h}$ using these methods. However, acetic acid was found not to be easily removed from [Emim] OAc or [Emim] $\mathrm{Cl}$ by evaporation, and a residual level of about $20 \%$ and $8 \%$ was respectively achieved, due to the high normal boiling point of acetic acid $\left(118^{\circ} \mathrm{C}\right)$. Liquid-liquid extraction for acetic acid removal was also unsuccessful due to the slow mass transfer, despite the extraction ability for acetic acid of the tested solvents. Esterification of acetic acid with alcohol in large excess at elevated temperature and pressure with subsequent distillation was found to be the best method to purify [Emim]OAc. Molecular distillation was used to recover [Amim] Cl used in homogeneous cellulose acetylation [215]. The IL was recovered with a combination of two techniques: conventional vacuum, to remove most of the water, and then the small amounts of acetic acid and water (less than $10 \%$ by mass) that are difficult to remove were disposed 
through molecular distillation. The IL was recycled and reused five times in the reaction, and the purity of recycled IL (for the fifth time) was as high as $99.56 \%$.

In theory, ILs can be reused, but after many cycles, heavy impurities can accumulate, or degradation can be suffered by the ILs. Moreover, in the derivatization processes, the use of organic or inorganic bases and the addition of stabilizers results in degradation of the biopolymer, and exhibits an enormous drawback for IL recycling and its repeated application [190]. An object of further investigation in cellulose processing is to develop a simple process for the preparation of cellulose derivatives which does not require the addition of any organic and/or inorganic bases, and which reduces the salt load and where the IL can be easily recycled and reused after purification.

\section{Conclusions}

Several aspects of cellulose processing in ILs have been reviewed. Cellulose has strong inter- and intramolecular hydrogen bonds, which limits the efficient application of this bio-polymer. Progress has been made on understanding the mechanism of cellulose dissolution in ILs, however, many details remain unknown. The advantages and disadvantages of using ILs in cellulose derivatization were discussed for esterification and etherification of cellulose. Key problems, such as the high cost of ILs and high viscosity of the reaction mixture, have been delaying their use in industrial cellulose processing. The chemicals (solvents and/or catalysts) employed should be carefully assessed regarding their biodegradability. Moreover, sustainability of cellulose processing with ILs could be given priority using effective recyclability and reuse of ILs, which is required for industrial implementation.

Acknowledgments: Authors thank the Marie Curie Program for the Project DoHip "Training program for the design of resource and energy efficient products for high pressure process", the Junta de Castilla y León for funding through the project VA295U14 and to the Spanish Ministry of Economy and Competitiveness for the project ENE2014-53459-R. MDB thank the Spanish Ministry of Economy and Competitiveness for the Ramón y Cajal research fellowship.

Author Contributions: M.D.B. conceived the review structure and content. J.M.L. performed the bibliographical search and wrote the paper. M.J.C. and A.M. contributed significantly with their expertise in developing the various versions of the paper.

Conflicts of Interest: The authors declare no conflict of interest.

\begin{tabular}{|c|c|}
\hline [Amim]Cl & 1-Allyl-3-methylimidazolium chloride \\
\hline$[\mathrm{Bmim}] \mathrm{BF}_{4}$ & 1-Butyl-3-methylimidazolium tetrafluoroborate \\
\hline$[\mathrm{Emim}] \mathrm{HCO}_{2}$ & 1-Ethyl-3-methylimidazolium formate \\
\hline$[\mathrm{Bmim}] \mathrm{PF}_{6}$ & 1-Butyl-3-methylimidazolium hexafluorophosphate \\
\hline$[$ Prmim $] \mathrm{HCO}_{2}$ & 1-Propyl-3-methylimidazolium formate \\
\hline$[$ Emim $] \mathrm{MeOSO}_{3}$ & 1-ethyl-3-methylimidazolium methylsulfate \\
\hline$[\mathrm{Amim}] \mathrm{HCO}_{2}$ & 1-Allyl-3-methylimidazolium formate \\
\hline$[$ Emim $] \mathrm{MeSO}_{3}$ & 1-Ethyl-3-methylimidazolium methanesulfonate \\
\hline$[\mathrm{Bmim}] \mathrm{OAc}$ & 1-Butyl-3-methylimidazolium acetate \\
\hline$[$ Emim $] \mathrm{CF}_{3} \mathrm{CO}_{2}$ & 1-Ethyl-3-methylimidazolium trifluoroacetate \\
\hline$[\mathrm{Bmim}] \mathrm{Cl}]$ & 1-Butyl-3-methylimidazolium chloride \\
\hline$[$ Emim]SCN & 1-Ethyl-3-methylimidazolium thiocyanate \\
\hline$[\mathrm{Bmim}] \mathrm{HCO}_{2}$ & 1-Butyl-3-methylimidazolium formate \\
\hline$\left[\mathrm{Emim} \mathrm{BF}_{4}\right.$ & 1-Ethyl-3-methylimidazolium tetrafluoroborate \\
\hline$[\mathrm{Emim}](\mathrm{MeO})_{2} \mathrm{PO}_{2}$ & 1-Ethyl-3-methylimidazolium dimethylphosphate \\
\hline$[\mathrm{Emim}] \mathrm{N}(\mathrm{CN})_{2}$ & 1-Ethyl-3-methylimidazolium dicyanamide \\
\hline$\left[\right.$ Emim] $(\mathrm{MeO}) \mathrm{HPO}_{2}$ & 1-Ethyl-3-methylimidazolium methylphosphonate \\
\hline [Emim]I & 1-Ethyl-3-methylimidazolium iodide \\
\hline
\end{tabular}




\begin{tabular}{|c|c|}
\hline$[\mathrm{Emim}](\mathrm{MeO}) \mathrm{MePO}_{2}$ & 1-Ethyl-3-methylimidazolium methyl methylphosphonate \\
\hline$[\mathrm{Emim}] \mathrm{PF}_{6}$ & 1-Ethyl-3-methylimidazolium hexafluorophosphate \\
\hline$[\mathrm{Emim}](\mathrm{EtO})_{2} \mathrm{PO}_{2}$ & 1-Ethyl-3-methylimidazolium diethylphosphate \\
\hline$[\mathrm{Bmim}] \mathrm{CH}_{3} \mathrm{SO}_{3}$ & 1-Butyl-3-methylimidazolium methanesulfonate \\
\hline$[\mathrm{Emim}] \mathrm{Cl}$ & 1-Ethyl-3-methylimidazolium chloride \\
\hline$[\mathrm{Bmim}] \mathrm{Br}$ & 1-Butyl-3-methylimidazolium bromide \\
\hline$[$ Emim $] \mathrm{H}_{2} \mathrm{PO}_{2}$ & 1-Ethyl-3-methylimidazolium dyhidrogenphosphate \\
\hline$\left[\right.$ Amim](MeO) $\mathrm{HPO}_{2}$ & 1-Allyl-3-methylimidazolium methylphosphonate \\
\hline$[$ Prmim $](\mathrm{MeO}) \mathrm{HPO}_{2}$ & 1-Propyl-3-methylimidazolium methylphosphonate \\
\hline$[\mathrm{Bmim}](\mathrm{MeO}) \mathrm{HPO}_{2}$ & 1-Butyl-3-methylimidazolium methylphosphonate \\
\hline [Emim]OAc & 1-Ethyl-3-methylimidazolium acetate \\
\hline ECOENG 41M & 1-Butyl-3-methylimidazolium 2-(2-methoxyethoxy)-ethylsulfate \\
\hline$[\mathrm{Emim}] \mathrm{CH}_{3} \mathrm{SO}_{3}$ & 1-Ethyl-3-methylimidazolium methanesulfonate \\
\hline$[\mathrm{Emim}] \mathrm{CF}_{3} \mathrm{SO}_{3}$ & 1-Ethyl-3-methylimidazolium: trifluoromethanesulfonate \\
\hline [Emim]Tos & 1-Ethyl-3-methylimidazolium tosylate \\
\hline$[\mathrm{Emim}] \mathrm{EtSO}_{4}$ & 1-Ethyl-3-methylimidazolium ethylsulfate \\
\hline$\left[\mathrm{Empy}_{\mathrm{E}} \mathrm{ESO}_{4}\right.$ & 1-Ethyl-3-methylpyridinium ethylsulfate \\
\hline$[\mathrm{Epy}] \mathrm{EtSO}_{4}$ & 1-Ethylpyridinium ethylsulfate \\
\hline$[$ EEpy]EtSO 4 & 1,2-Diethylpyridinium ethylsulfate \\
\hline$[\mathrm{Mpy}] \mathrm{CH}_{3} \mathrm{SO}_{4}$ & 1-methylpyridinium methylsulfate \\
\hline$[\mathrm{MMpy}] \mathrm{CH}_{3} \mathrm{SO}_{4}$ & 1,3-Dimethylpyridinium methylsulfate \\
\hline$[\mathrm{EMpy}] \mathrm{CH}_{3} \mathrm{SO}_{4}$ & 2-ethyl-1-methylpyridinium methylsulfate \\
\hline [Bmpyr]OAc & 1-Butyl-1-methylpyrrolidinium acetate \\
\hline$[\mathrm{Bmpyr}] \mathrm{CF}_{3} \mathrm{SO}_{3}$ & 1-Butyl-1-methylpyrrolidinium trifluoromethanesulfonate \\
\hline$[\mathrm{Bmpyr}](\mathrm{BtO}) \mathrm{HPO}_{2}$ & 1-Butyl-1-methylpyrrolidinium butylphosphonate \\
\hline$\left[\right.$ Empyr](EtO) $\mathrm{HPO}_{2}$ & 1-Ethyl-1-methylpyrrolidinium ethylphosphonate \\
\hline$[\mathrm{DBNH}] \mathrm{OAc}$ & 1,5-diaza-bicyclo[4.3.0]non-5-enium acetate \\
\hline [Emim]DEP & 1-Ethyl-3-methylimidazolium diethylphosphate \\
\hline$[\mathrm{Bdmim}] \mathrm{Cl}$ & 1-Butyl-2,3-methylimidazolium chloride \\
\hline [Admim]Br & 1-Allyl-2,3-methylimidazolium bromide \\
\hline$[\mathrm{Bmim}] \mathrm{OPr}$ & 1-butyl-3-methylimidazolium propionate \\
\hline
\end{tabular}

\section{References}

1. Lenzing. Focus Sustainability. Available online: http://www.lenzing.com/fileadmin/template/pdf/ konzern/nachhaltigkeit/Sustainability_Brochure_2008_EN.pdf (accessed on 10 May 2016).

2. Gardner, K.H.; Blackwell, J. The structure of native cellulose. Biopolymers 1974, 13, 1975-2001. [CrossRef]

3. Nishiyama, Y.; Sugiyama, J.; Chanzy, H.; Langan, P. Crystal structure and hydrogen bonding system in cellulose $\mathrm{I}_{\alpha}$ from synchrotron X-ray and neutron fiber diffraction. J. Am. Chem. Soc. 2003, 125, 14300-14306. [CrossRef] [PubMed]

4. Thygesen, A.; Oddershede, J.; Lilholt, H.; Thomsen, B.A.; Ståhl, K. On the determination of crystallinity and cellulose content in plant fibers. Cellulose 2005, 12, 563-576. [CrossRef]

5. Chandra, R.P.; Bura, R.; Mabee, W.E.; Berlin, A.; Pan, X.; Saddler, J.N. Substrate pretreatment: The key to effective enzymatic hydrolysis of lignocellulosics? In Biofuels; Olsson, L., Ed.; Springer: Berlin/Heidelberg, Germany, 2007; pp. 67-93.

6. Searle, S.; Malins, C. Availability of Cellulosic Residues in the EU. Available online: http:/ / theicct.org/sites / default/files/publications/ICCT_EUcellulosic-waste-residues_20131022.pdf (accessed on 10 May 2016).

7. Klemm, D.; Heublein, B.; Fink, H.-P.; Bohn, A. Cellulose: Fascinating biopolymer and sustainable raw material. Angew. Chem. Int. Ed. 2005, 44, 3358-3393. [CrossRef] [PubMed]

8. Zhang, K.; Pei, Z.; Wang, D. Organic solvent pretreatment of lignocellulosic biomass for biofuels and biochemicals: A review. Bioresour. Technol. 2016, 199, 21-33. [CrossRef] [PubMed]

9. The European Bioeconomy in 2030. Available online: http://www.epsoweb.org/file/560 (accessed on 10 May 2016). 
10. Bagheri, M.; Rodríguez, H.; Swatloski, R.P.; Spear, S.K.; Daly, D.T.; Rogers, R.D. Ionic liquid-based preparation of cellulose-dendrimer films as solid supports for enzyme immobilization. Biomacromolecules. 2008, 9, 381-387. [CrossRef] [PubMed]

11. Brennan, T.C.R.; Datta, S.; Blanch, H.W.; Simmons, B.A.; Holmes, B.M. Recovery of sugars from ionic liquid biomass liquor by solvent extraction. Bioenergy Res. 2010, 3, 123-133. [CrossRef]

12. Dibble, D.C.; Cheng, A.; George, A. Novel Compositions and Methods Useful for Ionic Liquid Treatment of Biomass. U.S. Patent 9,403,915, 2 August 2016.

13. Mikkola, J.-P.; Kirilin, A.; Tuuf, J.-C.; Pranovich, A.; Holmbom, B.; Kustov, L.M.; Murzin, D.Y.; Salmi, T. Ultrasound enhancement of cellulose processing in ionic liquids: From dissolution towards functionalization. Green Chem. 2007, 9, 1229-1237. [CrossRef]

14. Welton, T. Room-temperature ionic liquids. Solvents for synthesis and catalysis. Chem. Rev. 1999, 99, 2071-2084. [CrossRef] [PubMed]

15. Earle, M.; Seddon, K. Ionic liquids. Green solvents for the future. In Workshop on Sustainable Chemistry; Pure and Applied Chemistry: Venice, Italy, 2000; Volume 72, pp. 1391-1398.

16. Poole, C.F.; Poole, S.K. Extraction of organic compounds with room temperature ionic liquids. J. Chromatogr. A 2010, 1217, 2268-2286. [CrossRef] [PubMed]

17. Marsh, K.N.; Boxall, J.A.; Lichtenthaler, R. Room temperature ionic liquids and their mixtures-A review. Fluid Phase Equilib. 2004, 219, 93-98. [CrossRef]

18. Galiński, M.; Lewandowski, A.; Stępniak, I. Ionic liquids as electrolytes. Electrochim. Acta 2006, 51, 5567-5580. [CrossRef]

19. Welton, T. Ionic liquids in catalysis. Coord. Chem. Rev. 2004, 248, 2459-2477. [CrossRef]

20. Torimoto, T.; Tsuda, T.; Okazaki, K.-I.; Kuwabata, S. New frontiers in materials science opened by ionic liquids. Adv. Mater. 2010, 22, 1196-1221. [CrossRef] [PubMed]

21. Van Osch, D.J.G.P.; Kollau, L.J.B.M.; van den Bruinhorst, A.; Asikainen, S.; Rocha, M.A.A.; Kroon, M.C. Ionic liquids and deep eutectic solvents for lignocellulosic biomass fractionation. Phys. Chem. Chem. Phys. 2017, 19, 2636-2665. [CrossRef] [PubMed]

22. Zhao, D.; Wu, M.; Kou, Y.; Min, E. Ionic liquids: Applications in catalysis. Catal. Today 2002, 74, 157-189. [CrossRef]

23. Zhang, Z.; Song, J.; Han, B. Catalytic transformation of lignocellulose into chemicals and fuel products in ionic liquids. Chem. Rev. 2017, 117, 6834-6880. [CrossRef] [PubMed]

24. Olivier-Bourbigou, H.; Magna, L. Ionic liquids: Perspectives for organic and catalytic reactions. J. Mol. Catal. A Chem. 2002, 182-183, 419-437. [CrossRef]

25. Wasserscheid, P.; Keim, W. Ionic liquids-New "solutions" for transition metal catalysis. Angew. Chem. Int. Ed. 2000, 39, 3772-3789. [CrossRef]

26. Petkovic, M.; Ferguson, J.L.; Gunaratne, H.Q.N.; Ferreira, R.; Leitao, M.C.; Seddon, K.R.; Rebelo, L.P.N.; Pereira, C.S. Novel biocompatible cholinium-based ionic liquids-toxicity and biodegradability. Green Chem. 2010, 12, 643-649. [CrossRef]

27. Tang, S.; Baker, G.A.; Zhao, H. Ether- and alcohol-functionalized task-specific ionic liquids: Attractive properties and applications. Chem. Soc. Rev. 2012, 41, 4030-4066. [CrossRef] [PubMed]

28. Yuan, J.; Mecerreyes, D.; Antonietti, M. Poly(ionic liquid)s: An update. Prog. Polym. Sci. 2013, 38, $1009-1036$. [CrossRef]

29. Thuy Pham, T.P.; Cho, C.-W.; Yun, Y.-S. Environmental fate and toxicity of ionic liquids: A review. Water Res. 2010, 44, 352-372. [CrossRef] [PubMed]

30. Hallett, J.P.; Welton, T. Room-temperature ionic liquids: Solvents for synthesis and catalysis. 2. Chem. Rev. 2011, 111, 3508-3576. [CrossRef] [PubMed]

31. Steinrück, H.-P.; Wasserscheid, P. Ionic liquids in catalysis. Catal. Lett. 2015, 145, 380-397. [CrossRef]

32. Anderson, J.L.; Ding, R.; Ellern, A.; Armstrong, D.W. Structure and properties of high stability geminal dicationic ionic liquids. J. Am. Chem. Soc. 2005, 127, 593-604. [CrossRef] [PubMed]

33. Gardas, R.L.; Costa, H.F.; Freire, M.G.; Carvalho, P.J.; Marrucho, I.M.; Fonseca, I.M.A.; Ferreira, A.G.M.; Coutinho, J.A.P. Densities and derived thermodynamic properties of imidazolium-, pyridinium-, pyrrolidinium-, and piperidinium-based ionic liquids. J. Chem. Eng. Data 2008, 53, 805-811. [CrossRef]

34. Pádua, A.A.H.; Costa Gomes, M.F.; Canongia Lopes, J.N.A. Molecular solutes in ionic liquids: A structural perspective. Acc. Chem. Res. 2007, 40, 1087-1096. [CrossRef] [PubMed] 
35. Gardas, R.L.; Freire, M.G.; Carvalho, P.J.; Marrucho, I.M.; Fonseca, I.M.A.; Ferreira, A.G.M.; Coutinho, J.A.P. High-pressure densities and derived thermodynamic properties of imidazolium-based ionic liquids. J. Chem. Eng. Data 2007, 52, 80-88. [CrossRef]

36. Tokuda, H.; Hayamizu, K.; Ishii, K.; Susan, M.A.B.H.; Watanabe, M. Physicochemical properties and structures of room temperature ionic liquids. 2. Variation of alkyl chain length in imidazolium cation. J. Phys. Chem. B 2005, 109, 6103-6110. [CrossRef] [PubMed]

37. Chiappe, C.; Pieraccini, D. Ionic liquids: Solvent properties and organic reactivity. J. Phys. Org. Chem. 2005, 18, 275-297. [CrossRef]

38. Lazarus, L.L.; Riche, C.T.; Malmstadt, N.; Brutchey, R.L. Effect of ionic liquid impurities on the synthesis of silver nanoparticles. Langmuir 2012, 28, 15987-15993. [CrossRef] [PubMed]

39. Cassol, C.C.; Ebeling, G.; Ferrera, B.; Dupont, J. A simple and practical method for the preparation and purity determination of halide-free imidazolium ionic liquids. Adv. Synth. Catal. 2006, 348, 243-248. [CrossRef]

40. Burrell, A.K.; Sesto, R.E.D.; Baker, S.N.; McCleskey, T.M.; Baker, G.A. The large scale synthesis of pure imidazolium and pyrrolidinium ionic liquids. Green Chem. 2007, 9, 449-454. [CrossRef]

41. Holbrey, J.D.; Seddon, K.R.; Wareing, R. A simple colorimetric method for the quality control of 1-alkyl-3-methylimidazolium ionic liquid precursors. Green Chem. 2001, 3, 33-36. [CrossRef]

42. Wheeler, J.L.; Dreyer, C.B.; Poshusta, J.; Martin, J.L.; Porter, J.M. Real-time monitoring of room-temperature ionic liquid purity through optical diode-based sensing. Sens. Actuators B 2015, 220, 309-313. [CrossRef]

43. Swatloski, R.P.; Spear, S.K.; Holbrey, J.D.; Rogers, R.D. Dissolution of cellose with ionic liquids. J. Am. Chem. Soc. 2002, 124, 4974-4975. [CrossRef] [PubMed]

44. Pu, Y.; Jiang, N.; Ragauskas, A.J. Ionic liquid as a green solvent for lignin. J. Wood Chem. Technol. 2007, 27, 23-33. [CrossRef]

45. Pinkert, A.; Goeke, D.F.; Marsh, K.N.; Pang, S. Extracting wood lignin without dissolving or degrading cellulose: Investigations on the use of food additive-derived ionic liquids. Green Chem. 2011, 13, 3124-3136. [CrossRef]

46. Chatel, G.; Rogers, R.D. Review: Oxidation of lignin using ionic liquids-An innovative strategy to produce renewable chemicals. ACS Sustain. Chem. Eng. 2014, 2, 322-339. [CrossRef]

47. Qin, Y.; Lu, X.; Sun, N.; Rogers, R.D. Dissolution or extraction of crustacean shells using ionic liquids to obtain high molecular weight purified chitin and direct production of chitin films and fibers. Green Chem. 2010, 12, 968-971. [CrossRef]

48. Wu, Y.; Sasaki, T.; Irie, S.; Sakurai, K. A novel biomass-ionic liquid platform for the utilization of native chitin. Polymer 2008, 49, 2321-2327. [CrossRef]

49. Kadokawa, J.-I. Dissolution, gelation, functionalization, and material preparation of chitin using ionic liquids. Pure Appl. Chem. 2016, 88, 621. [CrossRef]

50. Xu, A.; Zhang, Y.; Zhao, Y.; Wang, J. Cellulose dissolution at ambient temperature: Role of preferential solvation of cations of ionic liquids by a cosolvent. Carbohydr. Polym. 2013, 92, 540-544. [CrossRef] [PubMed]

51. Ma, H.; Zhou, B.; Li, H.-S.; Li, Y.-Q.; Ou, S.-Y. Green composite films composed of nanocrystalline cellulose and a cellulose matrix regenerated from functionalized ionic liquid solution. Carbohydr. Polym. 2011, 84, 383-389. [CrossRef]

52. Ohno, E.; Miyafuji, H. Reaction behavior of cellulose in an ionic liquid, 1-ethyl-3-methylimidazolium chloride. J. Wood Sci. 2013, 59, 221-228. [CrossRef]

53. Wang, X.; Li, H.; Cao, Y.; Tang, Q. Cellulose extraction from wood chip in an ionic liquid 1-allyl-3-methylimidazolium chloride (amimcl). Bioresour. Technol. 2011, 102, 7959-7965. [CrossRef] [PubMed]

54. Hameed, N.; Guo, Q. Blend films of natural wool and cellulose prepared from an ionic liquid. Cellulose 2010, 17, 803-813. [CrossRef]

55. Ding, Z.-D.; Chi, Z.; Gu, W.-X.; Gu, S.-M.; Liu, J.-H.; Wang, H.-J. Theoretical and experimental investigation on dissolution and regeneration of cellulose in ionic liquid. Carbohydr. Polym. 2012, 89, 7-16. [CrossRef] [PubMed]

56. Du, H.; Qian, X. The effects of acetate anion on cellulose dissolution and reaction in imidazolium ionic liquids. Carbohydr. Res. 2011, 346, 1985-1990. [CrossRef] [PubMed] 
57. Remsing, R.C.; Hernandez, G.; Swatloski, R.P.; Massefski, W.W.; Rogers, R.D.; Moyna, G. Solvation of carbohydrates in $\mathrm{N}, \mathrm{N}^{\prime}$-dialkylimidazolium ionic liquids: A multinuclear NMR spectroscopy study. J. Phys. Chem. B 2008, 112, 11071-11078. [CrossRef] [PubMed]

58. Guo, J.; Zhang, D.; Duan, C.; Liu, C. Probing anion-cellulose interactions in imidazolium-based room temperature ionic liquids: A density functional study. Carbohydr. Res. 2010, 345, 2201-2205. [CrossRef] [PubMed]

59. Zhang, H.; Wu, J.; Zhang, J.; He, J. 1-allyl-3-methylimidazolium chloride room temperature ionic liquid: A new and powerful nonderivatizing solvent for cellulose. Macromolecules 2005, 38, 8272-8277. [CrossRef]

60. Youngs, T.G.A.; Hardacre, C.; Holbrey, J.D. Glucose solvation by the ionic liquid 1,3-dimethylimidazolium chloride: A simulation study. J. Phys. Chem. B 2007, 111, 13765-13774. [CrossRef] [PubMed]

61. Liu, D.-T.; Xia, K.-F.; Cai, W.-H.; Yang, R.-D.; Wang, L.-Q.; Wang, B. Investigations about dissolution of cellulose in the 1-allyl-3-alkylimidazolium chloride ionic liquids. Carbohydr. Polym. 2012, 87, 1058-1064. [CrossRef]

62. Liu, H.; Sale, K.L.; Holmes, B.M.; Simmons, B.A.; Singh, S. Understanding the interactions of cellulose with ionic liquids: A molecular dynamics study. J. Phys. Chem. B 2010, 114, 4293-4301. [CrossRef] [PubMed]

63. Lindman, B.; Karlström, G.; Stigsson, L. On the mechanism of dissolution of cellulose. J. Mol. Liq. 2010, 156, 76-81. [CrossRef]

64. Wu, J.; Zhang, J.; Zhang, H.; He, J.; Ren, Q.; Guo, M. Homogeneous acetylation of cellulose in a new ionic liquid. Biomacromolecules 2004, 5, 266-268. [CrossRef] [PubMed]

65. Isogai, A.; Atalla, R.H. Dissolution of cellulose in aqueous naoh solutions. Cellulose 1998, 5, 309-319. [CrossRef]

66. El Seoud, O.A.; Marson, G.A.; Ciacco, G.T.; Frollini, E. An efficient, one-pot acylation of cellulose under homogeneous reaction conditions. Macromol. Chem. Phys. 2000, 201, 882-889. [CrossRef]

67. Heinze, T.; Liebert, T.; Klüfers, P.; Meister, F. Carboxymethylation of cellulose in unconventional media. Cellulose 1999, 6, 153-165. [CrossRef]

68. Ciacco, G.T.; Liebert, T.F.; Frollini, E.; Heinze, T.J. Application of the solvent dimethyl sulfoxide/tetrabutyl-ammonium fluoride trihydrate as reaction medium for the homogeneous acylation of sisal cellulose. Cellulose 2003, 10, 125-132. [CrossRef]

69. Nagel, M.C.V.; Heinze, T. Esterification of cellulose with acyl-1h-benzotriazole. Polym. Bull. 2010, 65, 873-881. [CrossRef]

70. Hussain, M.A.; Liebert, T.; Heinze, T. Acylation of cellulose with $\mathrm{N}, \mathrm{N}^{\prime}$-carbonyldiimidazole-activated acids in the novel solvent dimethyl sulfoxide/tetrabutylammonium fluoride. Macromol. Rapid Commun. 2004, 25, 916-920. [CrossRef]

71. Köhler, S.; Heinze, T. New solvents for cellulose: Dimethyl sulfoxide/ammonium fluorides. Macromol. Biosci. 2007, 7, 307-314. [CrossRef] [PubMed]

72. Jeihanipour, A.; Karimi, K.; Taherzadeh, M.J. Enhancement of ethanol and biogas production from high-crystalline cellulose by different modes of nmo pretreatment. Biotechnol. Bioeng. 2010, 105, 469-476. [CrossRef] [PubMed]

73. Yuan, H.; Nishiyama, Y.; Kuga, S. Surface esterification of cellulose by vapor-phase treatmentwith trifluoroacetic anhydride. Cellulose 2005, 12, 543-549. [CrossRef]

74. Kim, H.-T.; Lee, K. Application of insoluble cellulose xanthate for the removal of heavy metals from aqueous solution. Korean J. Chem. Eng. 1999, 16, 298-302. [CrossRef]

75. Brewer, R. Process for Preparing Cellulose Sulfate Esters. U.S. Patent 4,480,091, 30 October 1984.

76. Pinkert, A.; Marsh, K.N.; Pang, S.; Staiger, M.P. Ionic liquids and their interaction with cellulose. Chem. Rev. 2009, 109, 6712-6728. [CrossRef] [PubMed]

77. Zhu, S.; Wu, Y.; Chen, Q.; Yu, Z.; Wang, C.; Jin, S.; Ding, Y.; Wu, G. Dissolution of cellulose with ionic liquids and its application: A mini-review. Green Chem. 2006, 8, 325-327. [CrossRef]

78. Mäki-Arvela, P.; Anugwom, I.; Virtanen, P.; Sjöholm, R.; Mikkola, J.P. Dissolution of lignocellulosic materials and its constituents using ionic liquids-A review. Ind. Crops Prod. 2010, 32, 175-201. [CrossRef]

79. Isik, M.; Sardon, H.; Mecerreyes, D. Ionic liquids and cellulose: Dissolution, chemical modification and preparation of new cellulosic materials. Int. J. Mol. Sci. 2014, 15, 11922-11940. [CrossRef] [PubMed]

80. El Seoud, O.A.; Koschella, A.; Fidale, L.C.; Dorn, S.; Heinze, T. Applications of ionic liquids in carbohydrate chemistry: A window of opportunities. Biomacromolecules. 2007, 8, 2629-2647. [CrossRef] [PubMed] 
81. Wang, H.; Gurau, G.; Rogers, R.D. Ionic liquid processing of cellulose. Chem. Soc. Rev. 2012, 41, $1519-1537$. [CrossRef] [PubMed]

82. Yuan, X.; Cheng, G. From cellulose fibrils to single chains: Understanding cellulose dissolution in ionic liquids. Phys. Chem. Chem. Phys. 2015, 17, 31592-31607. [CrossRef] [PubMed]

83. Stark, A.; Sellin, M.; Ondruschka, B.; Massonne, K. The effect of hydrogen bond acceptor properties of ionic liquids on their cellulose solubility. Sci. China Chem. 2012, 55, 1663-1670. [CrossRef]

84. Kamlet, M.J.; Taft, R.W. The solvatochromic comparison method. I. The beta.-scale of solvent hydrogen-bond acceptor (HBA) basicities. J. Am. Chem. Soc. 1976, 98, 377-383. [CrossRef]

85. Avent, A.G.; Chaloner, P.A.; Day, M.P.; Seddon, K.R.; Welton, T. Evidence for hydrogen bonding in solutions of 1-ethyl-3-methylimidazolium halides, and its implications for room-temperature halogenoaluminate(III) ionic liquids. J. Chem. Soc. Dalton Trans. 1994, 3405-3413. [CrossRef]

86. Crowhurst, L.; Mawdsley, P.R.; Perez-Arlandis, J.M.; Salter, P.A.; Welton, T. Solvent-solute interactions in ionic liquids. Phys. Chem. Chem. Phys. 2003, 5, 2790-2794. [CrossRef]

87. Fukaya, Y.; Sugimoto, A.; Ohno, H. Superior solubility of polysaccharides in low viscosity, polar, and halogen-free 1,3-dialkylimidazolium formates. Biomacromolecules 2006, 7, 3295-3297. [CrossRef] [PubMed]

88. Ohno, H.; Fukaya, Y. Task specific ionic liquids for cellulose technology. Chem. Lett. 2009, 38, 2-7. [CrossRef]

89. Fukaya, Y.; Hayashi, K.; Wada, M.; Ohno, H. Cellulose dissolution with polar ionic liquids under mild conditions: Required factors for anions. Green Chem. 2008, 10, 44-46. [CrossRef]

90. Cao, Y.; Chen, Y.; Wang, X.; Mu, T. Predicting the hygroscopicity of imidazolium-based ILs varying in anion by hydrogen-bonding basicity and acidity. RSC Adv. 2014, 4, 5169-5176. [CrossRef]

91. Lungwitz, R.; Spange, S. A hydrogen bond accepting (HBA) scale for anions, including room temperature ionic liquids. New J. Chem. 2008, 32, 392-394. [CrossRef]

92. Ngo, H.L.; LeCompte, K.; Hargens, L.; McEwen, A.B. Thermal properties of imidazolium ionic liquids. Thermochim. Acta 2000, 357-358, 97-102. [CrossRef]

93. Abe, M.; Fukaya, Y.; Ohno, H. Extraction of polysaccharides from bran with phosphonate or phosphinate-derived ionic liquids under short mixing time and low temperature. Green Chem. 2010, 12, 1274-1280. [CrossRef]

94. Bonhôte, P.; Dias, A.-P.; Papageorgiou, N.; Kalyanasundaram, K.; Grätzel, M. Hydrophobic, highly conductive ambient-temperature molten salts. Inorg. Chem. 1996, 35, 1168-1178. [CrossRef] [PubMed]

95. Zhang, S.; Qi, X.; Ma, X.; Lu, L.; Zhang, Q.; Deng, Y. Investigation of cation-anion interaction in 1-(2-hydroxyethyl)-3-methylimidazolium-based ion pairs by density functional theory calculations and experiments. J. Phys. Org. Chem. 2012, 25, 248-257. [CrossRef]

96. Doherty, T.V.; Mora-Pale, M.; Foley, S.E.; Linhardt, R.J.; Dordick, J.S. Ionic liquid solvent properties as predictors of lignocellulose pretreatment efficacy. Green Chem. 2010, 12, 1967-1975. [CrossRef]

97. Lungwitz, R.; Strehmel, V.; Spange, S. The dipolarity/polarisability of 1-alkyl-3-methylimidazolium ionic liquids as function of anion structure and the alkyl chain length. New J. Chem. 2010, 34, 1135-1140. [CrossRef]

98. Oehlke, A.; Hofmann, K.; Spange, S. New aspects on polarity of 1-alkyl-3-methylimidazolium salts as measured by solvatochromic probes. New J. Chem. 2006, 30, 533-536. [CrossRef]

99. Ab Rani, M.A.; Brant, A.; Crowhurst, L.; Dolan, A.; Lui, M.; Hassan, N.H.; Hallett, J.P.; Hunt, P.A.; Niedermeyer, H.; Perez-Arlandis, J.M.; et al. Understanding the polarity of ionic liquids. Phys. Chem. Chem. Phys. 2011, 13, 16831-16840. [CrossRef] [PubMed]

100. Gaciño, F.M.; Regueira, T.; Lugo, L.; Comuñas, M.J.P.; Fernández, J. Influence of molecular structure on densities and viscosities of several ionic liquids. J. Chem. Eng. Data 2011, 56, 4984-4999. [CrossRef]

101. Tokuda, H.; Ishii, K.; Susan, M.A.B.H.; Tsuzuki, S.; Hayamizu, K.; Watanabe, M. Physicochemical properties and structures of room-temperature ionic liquids. 3. Variation of cationic structures. J. Phys. Chem. B 2006, 110, 2833-2839. [CrossRef] [PubMed]

102. Gardas, R.L.; Coutinho, J.A.P. Group contribution methods for the prediction of thermophysical and transport properties of ionic liquids. AlChE J. 2009, 55, 1274-1290. [CrossRef]

103. Crosthwaite, J.M.; Muldoon, M.J.; Dixon, J.K.; Anderson, J.L.; Brennecke, J.F. Phase transition and decomposition temperatures, heat capacities and viscosities of pyridinium ionic liquids. J. Chem. Thermodyn. 2005, 37, 559-568. [CrossRef] 
104. Almeida, H.F.D.; Passos, H.; Lopes-da-Silva, J.A.; Fernandes, A.M.; Freire, M.G.; Coutinho, J.A.P. Thermophysical properties of five acetate-based ionic liquids. J. Chem. Eng. Data 2012, 57, 3005-3013. [CrossRef]

105. Huddleston, J.G.; Visser, A.E.; Reichert, W.M.; Willauer, H.D.; Broker, G.A.; Rogers, R.D. Characterization and comparison of hydrophilic and hydrophobic room temperature ionic liquids incorporating the imidazolium cation. Green Chem. 2001, 3, 156-164. [CrossRef]

106. Wu, D.; Wu, B.; Zhang, Y.M.; Wang, H.P. Density, viscosity, refractive index and conductivity of 1-allyl-3-methylimidazolium chloride + water mixture. J. Chem. Eng. Data 2010, 55, 621-624. [CrossRef]

107. Freire, M.G.; Teles, A.R.R.; Rocha, M.A.A.; Schröder, B.; Neves, C.M.S.S.; Carvalho, P.J.; Evtuguin, D.V.; Santos, L.M.N.B.F.; Coutinho, J.A.P. Thermophysical characterization of ionic liquids able to dissolve biomass. J. Chem. Eng. Data 2011, 56, 4813-4822. [CrossRef]

108. Fröba, A.P.; Kremer, H.; Leipertz, A. Density, refractive index, interfacial tension, and viscosity of ionic liquids $[\mathrm{EMIM}]\left[\mathrm{EtSO}_{4}\right],[\mathrm{EMIM}]\left[\mathrm{NTf}_{2}\right],[\mathrm{EMIM}]\left[\mathrm{N}(\mathrm{CN})_{2}\right]$, and $[\mathrm{OMA}]\left[\mathrm{NTf}_{2}\right]$ in dependence on temperature at atmospheric pressure. J. Phys. Chem. B 2008, 112, 12420-12430. [CrossRef] [PubMed]

109. Gómez, E.; Calvar, N.; Domínguez, Á.; Macedo, E.A. Synthesis and temperature dependence of physical properties of four pyridinium-based ionic liquids: Influence of the size of the cation. J. Chem. Thermodyn. 2010, 42, 1324-1329.

110. Zarrougui, R.; Raouafi, N.; Lemordant, D. New series of green cyclic ammonium-based room temperature ionic liquids with alkylphosphite-containing anion: Synthesis and physicochemical characterization. J. Chem. Eng. Data 2014, 59, 1193-1201. [CrossRef]

111. Seddon, K.; Stark, A.; Torres, M. Influence of chloride, water, and organic solvents on the physical properties of ionic liquids. In Proceedings of the 15th International Conference on Physical Organic Chemistry (ICPOC 15), Gothenburg, Sweden, 8-13 July 2000; Volume 72, pp. 2275-2287.

112. Xu, H.; Zhao, D.; Xu, P.; Liu, F.; Gao, G. Conductivity and viscosity of 1-allyl-3-methyl-imidazolium chloride + water and + ethanol from $293.15 \mathrm{~K}$ to 333.15 K. J. Chem. Eng. Data 2005, 50, 133-135. [CrossRef]

113. Lu, F.; Cheng, B.; Song, J.; Liang, Y. Rheological characterization of concentrated cellulose solutions in 1-allyl-3-methylimidazolium chloride. J. Appl. Polym. Sci. 2012, 124, 3419-3425. [CrossRef]

114. Cao, Y.; Wu, J.; Meng, T.; Zhang, J.; He, J.; Li, H.; Zhang, Y. Acetone-soluble cellulose acetates prepared by one-step homogeneous acetylation of cornhusk cellulose in an ionic liquid 1-allyl-3-methylimidazolium chloride (AmimCl). Carbohydr. Polym. 2007, 69, 665-672. [CrossRef]

115. Cao, Y.; Zhang, J.; He, J.; Li, H.; Zhang, Y. Homogeneous acetylation of cellulose at relatively high concentrations in an ionic liquid. Chin. J. Chem. Eng. 2010, 18, 515-522. [CrossRef]

116. Kosan, B.; Michels, C.; Meister, F. Dissolution and forming of cellulose with ionic liquids. Cellulose 2008, 15, 59-66. [CrossRef]

117. Le, K.A.; Rudaz, C.; Budtova, T. Phase diagram, solubility limit and hydrodynamic properties of cellulose in binary solvents with ionic liquid. Carbohydr. Polym. 2014, 105, 237-243. [CrossRef] [PubMed]

118. Lv, Y.; Wu, J.; Zhang, J.; Niu, Y.; Liu, C.-Y.; He, J.; Zhang, J. Rheological properties of cellulose/ionic liquid/dimethylsulfoxide (DMSO) solutions. Polymer 2012, 53, 2524-2531. [CrossRef]

119. Härdelin, L.; Thunberg, J.; Perzon, E.; Westman, G.; Walkenström, P.; Gatenholm, P. Electrospinning of cellulose nanofibers from ionic liquids: The effect of different cosolvents. J. Appl. Polym. Sci. 2012, 125, 1901-1909. [CrossRef]

120. Ahosseini, A.; Ortega, E.; Sensenich, B.; Scurto, A.M. Viscosity of $n$-alkyl-3-methyl-imidazolium bis(trifluoromethylsulfonyl)amide ionic liquids saturated with compressed $\mathrm{CO}_{2}$. Fluid Phase Equilib. 2009, 286, 72-78. [CrossRef]

121. Blanchard, L.A.; Hancu, D.; Beckman, E.J.; Brennecke, J.F. Green processing using ionic liquids and $\mathrm{CO}_{2}$. Nature 1999, 399, 28-29. [CrossRef]

122. Sun, X.; Chi, Y.; Mu, T. Studies on staged precipitation of cellulose from an ionic liquid by compressed carbon dioxide. Green Chem. 2014, 16, 2736-2744. [CrossRef]

123. Barber, P.S.; Griggs, C.S.; Gurau, G.; Liu, Z.; Li, S.; Li, Z.; Lu, X.; Zhang, S.; Rogers, R.D. Coagulation of chitin and cellulose from 1-ethyl-3-methylimidazolium acetate ionic-liquid solutions using carbon dioxide. Angew. Chem. Int. Ed. 2013, 52, 12350-12353. [CrossRef] [PubMed] 
124. Liu, Z.; Wu, W.; Han, B.; Dong, Z.; Zhao, G.; Wang, J.; Jiang, T.; Yang, G. Study on the phase behaviors, viscosities, and thermodynamic properties of $\mathrm{CO}_{2} /[\mathrm{C} 4 \mathrm{mim}][\mathrm{PF} 6] /$ methanol system at elevated pressures. Chem. Eur. J. 2003, 9, 3897-3903. [CrossRef] [PubMed]

125. Tomida, D.; Kenmochi, S.; Qiao, K.; Bao, Q.; Yokoyama, C. Viscosity of ionic liquid mixtures of 1-alkyl-3-methylimidazolium hexafluorophosphate $+\mathrm{CO}_{2}$. Fluid Phase Equilib. 2011, 307, 185-189. [CrossRef]

126. Tomida, D.; Kumagai, A.; Qiao, K.; Yokoyama, C. Viscosity of 1-butyl-3-methylimidazolium hexafluorophosphate $+\mathrm{CO}_{2}$ mixture. J. Chem. Eng. Data 2007, 52, 1638-1640. [CrossRef]

127. Lopes, J.M.; Kareth, S.; Bermejo, M.D.; Martín, Á.; Weidner, E.; Cocero, M.J. Experimental determination of viscosities and densities of mixtures carbon dioxide + 1-allyl-3-methylimidazolium chloride. Viscosity correlation. J. Supercrit. Fluids 2016, 111, 91-96. [CrossRef]

128. Iguchi, M.; Kasuya, K.; Sato, Y.; Aida, T.M.; Watanabe, M.; Smith, R.L. Viscosity reduction of cellulose + 1-butyl-3-methylimidazolium acetate in the presence of $\mathrm{CO}_{2}$. Cellulose 2013, 20, 1353-1367. [CrossRef]

129. Visser, A.E.; Reichert, W.M.; Swatloski, R.P.; Willauer, H.D.; Huddleston, J.G.; Rogers, R.D. Characterization of hydrophilic and hydrophobic ionic liquids: Alternatives to volatile organic compounds for liquid-liquid separations. In Ionic Liquids; American Chemical Society: Washington, DC, USA, 2002; Volume 818, pp. 289-308.

130. Tran, C.D.; De Paoli Lacerda, S.H.; Oliveira, D. Absorption of water by room-temperature ionic liquids: Effect of anions on concentration and state of water. Appl. Spectrosc. 2003, 57, 152-157. [CrossRef] [PubMed]

131. Cammarata, L.; Kazarian, S.G.; Salter, P.A.; Welton, T. Molecular states of water in room temperature ionic liquids. Phys. Chem. Chem. Phys. 2001, 3, 5192-5200. [CrossRef]

132. Liu, H.; Sale, K.L.; Simmons, B.A.; Singh, S. Molecular dynamics study of polysaccharides in binary solvent mixtures of an ionic liquid and water. J. Phys. Chem. B 2011, 115, 10251-10258. [CrossRef] [PubMed]

133. Rabideau, B.D.; Ismail, A.E. Mechanisms of hydrogen bond formation between ionic liquids and cellulose and the influence of water content. Phys. Chem. Chem. Phys. 2015, 17, 5767-5775. [CrossRef] [PubMed]

134. Lenzing. Sustainability Report. Available online: http://www.lenzing.com/fileadmin/template/pdf/ konzern/nachhaltigkeit/Sustainability_Report_2012_EN.pdf (accessed on 19 February 2016).

135. Kang, H.; Liu, R.; Huang, Y. Cellulose derivatives and graft copolymers as blocks for functional materials. Polym. Int. 2013, 62, 338-344. [CrossRef]

136. Varshney, V.K.; Naithani, S. Chemical functionalization of cellulose derived from nonconventional sources. In Cellulose Fibers: Bio- and Nano-Polymer Composites; Kalia, S., Kaith, B.S., Kaur, I., Eds.; Springer: Berlin/Heidelberg, Germany, 2011; pp. 43-60.

137. Seymour, G.W.; White, B.B. Preparation of Cellulose Esters. U.S. Patent 2,363,091, 21 November 1944.

138. Heinze, T.; Liebert, T. Unconventional methods in cellulose functionalization. Prog. Polym. Sci. 2001, 26, 1689-1762. [CrossRef]

139. Eastman. Eastman Cellulose-Based Specialty Polymers. Available online: http://www.eastman.com/ Literature_Center/E/E325.pdf (accessed on 19 February 2016).

140. Edgar, K.J. Cellulose esters in drug delivery. Cellulose 2007, 14, 49-64. [CrossRef]

141. Tang, S.; Li, X.; Wang, F.; Liu, G.; Li, Y.; Pan, F. Synthesis and hplc chiral recognition of regioselectively carbamoylated cellulose derivatives. Chirality 2012, 24, 167-173. [CrossRef] [PubMed]

142. Wondraczek, H.; Pfeifer, A.; Heinze, T. Water soluble photoactive cellulose derivatives: Synthesis and characterization of mixed 2-[(4-methyl-2-oxo-2H-chromen-7-yl)oxy]acetic acid-(3-carboxypropyl)trimethylammonium chloride esters of cellulose. Cellulose 2012, 19, 1327-1335. [CrossRef]

143. Trombino, S.; Cassano, R.; Bloise, E.; Muzzalupo, R.; Leta, S.; Puoci, F.; Picci, N. Design and synthesis of cellulose derivatives with antioxidant activity. Macromol. Biosci. 2008, 8, 86-95. [CrossRef] [PubMed]

144. Karakawa, M.; Chikamatsu, M.; Yoshida, Y.; Azumi, R.; Yase, K.; Nakamoto, C. Organic memory device based on carbazole-substituted cellulose. Macromol. Rapid Commun. 2007, 28, 1479-1484. [CrossRef]

145. Thakur, V.K.; Thakur, M.K.; Gupta, R.K. Rapid synthesis of graft copolymers from natural cellulose fibers. Carbohydr. Polym. 2013, 98, 820-828. [CrossRef] [PubMed]

146. Fox, S.C.; Li, B.; Xu, D.; Edgar, K.J. Regioselective esterification and etherification of cellulose: A review. Biomacromolecules 2011, 12, 1956-1972. [CrossRef] [PubMed]

147. Dow. Cellulose Ethers. Available online: http://www.dowconstructionchemicals.com/na/en/pdfs/83200226.pdf (accessed on 25 February 2016). 
148. Amin, M.; Abbas, N.S.; Hussain, M.A.; Edgar, K.J.; Tahir, M.N.; Tremel, W.; Sher, M. Cellulose ether derivatives: A new platform for prodrug formation of fluoroquinolone antibiotics. Cellulose 2015, 22, 2011-2022. [CrossRef]

149. Malm, C.; Tanghe, L. Chemical reactions in the making of cellulose acetate. Ind. Eng. Chem. 1955, 47, 995-999. [CrossRef]

150. Hearon, W.M.; Hiatt, G.D.; Fordyce, C.R. Cellulose trityl ether1a. J. Am. Chem. Soc. 1943, 65, $2449-2452$. [CrossRef]

151. Xia, K.; Chen, J.; Yang, R.; Cheng, F.; Liu, D. Green synthesis and crystal structure of regioselectively substituting 6-O-tritylcellulose derivatives. J. Biobased. Mater. Bioenergy 2014, 8, 587-593. [CrossRef]

152. Marson, G.A.; El Seoud, O.A. A novel, efficient procedure for acylation of cellulose under homogeneous solution conditions. J. Appl. Polym. Sci. 1999, 74, 1355-1360. [CrossRef]

153. Sassi, J.-F.; Chanzy, H. Ultrastructural aspects of the acetylation of cellulose. Cellulose 1995, 2, 111-127. [CrossRef]

154. Gannon, J.M.; Graveson, I.; Mortimer, S.A. Process for the Manufacture of Lyocell Fiber. U.S. Patent 5,725,821, 10 March 1998.

155. Sixta, H.; Michud, A.; Hauru, L.; Asaadi, S.; Ma, Y.; King, A.W.T.; Kilpeläinen, I.; Hummel, M. Ioncell-F: A high-strength regenerated cellulose fiber. Nord. Pulp Pap. Res. J. 2015, 30, 43-57. [CrossRef]

156. Fink, H.P.; Weigel, P.; Purz, H.J.; Ganster, J. Structure formation of regenerated cellulose materials from nmmo-solutions. Prog. Polym. Sci. 2001, 26, 1473-1524. [CrossRef]

157. Röder, T.; Moosbauer, J.; Kliba, G.; Schlader, S.; Zuckerstätter, G.; Sixta, H. Comparative characterisation of man-made regenerated cellulose fibers. Lenzinger Berichte 2009, 87, 98-105.

158. Mayr, G.; Zeppetzauer, F.; Zweckmair, T.; Bauer, D.; Hild, S.; Potthast, A.; Rosenau, T.; Röder, T. The reactions of cellulose and hemicellulose degradation products in the viscose fiber spin bath. Lenzinger Berichte 2015, 92, 53-58.

159. Röder, T.; Moosbauer, J.; Wöss, K.; Schlader, S.; Kraft, G. Man-made cellulose fibers-A comparison based on morphology and mechanical properties. Lenzinger Berichte 2013, 91, 7-12.

160. Kim, S.-J.; Jang, J. Effect of degree of polymerization on the mechanical properties of regenerated cellulose fibers using synthesized 1-allyl-3-methylimidazolium chloride. Fibers Polym. 2013, 14, 909-914. [CrossRef]

161. Nemec, H. Fibrillation of cellulose materials-Can previous literature offer s solution? Lenzinger Berichte 1994, 9, 69-72.

162. Mortimer, S.A.; Péguy, A.A. Methods for reducing the tendency of lyocell fibers to fibrillate. J. Appl. Polym. Sci. 1996, 60, 305-316. [CrossRef]

163. Zhang, W.; Okubayashi, S.; Bechtold, T. Fibrillation tendency of cellulosic fibers. Part 1: Effects of swelling. Cellulose 2005, 12, 267-273. [CrossRef]

164. Zhang, W.; Okubayashi, S.; Bechtold, T. Fibrillation tendency of cellulosic fibers-Part 3. Effects of alkali pretreatment of lyocell fiber. Carbohydr. Polym. 2005, 59, 173-179. [CrossRef]

165. Rosenau, T.; Potthast, A.; Sixta, H.; Kosma, P. The chemistry of side reactions and byproduct formation in the system NMMO/cellulose (lyocell process). Prog. Polym. Sci. 2001, 26, 1763-1837. [CrossRef]

166. Hermanutz, F.; Gähr, F.; Uerdingen, E.; Meister, F.; Kosan, B. New developments in dissolving and processing of cellulose in ionic liquids. Macromol. Symp. 2008, 262, 23-27. [CrossRef]

167. De la Parra, C.J.; Navarrete, A.; Bermejo, M.D.; Cocero, M.J. Patents review on lignocellulosic biomass processing using ionic liquids. Recent Pat. Eng. 2012, 6, 159-181. [CrossRef]

168. Luan, Y.; Zhang, J.; Zhan, M.; Wu, J.; Zhang, J.; He, J. Highly efficient propionylation and butyralation of cellulose in an ionic liquid catalyzed by 4-dimethylminopyridine. Carbohydr. Polym. 2013, 92, 307-311. [CrossRef] [PubMed]

169. Gericke, M.; Fardim, P.; Heinze, T. Ionic liquids-Promising but challenging solvents for homogeneous derivatization of cellulose. Molecules 2012, 17, 7458-7502. [CrossRef] [PubMed]

170. Huang, K.; Wang, B.; Cao, Y.; Li, H.; Wang, J.; Lin, W.; Mu, C.; Liao, D. Homogeneous preparation of cellulose acetate propionate (CAP) and cellulose acetate butyrate (CAB) from sugarcane bagasse cellulose in ionic liquid. J. Agric. Food. Chem. 2011, 59, 5376-5381. [CrossRef] [PubMed]

171. Heinze, T.; Schwikal, K.; Barthel, S. Ionic liquids as reaction medium in cellulose functionalization. Macromol. Biosci. 2005, 5, 520-525. [CrossRef] [PubMed] 
172. Granström, M.; Kavakka, J.; King, A.; Majoinen, J.; Mäkelä, V.; Helaja, J.; Hietala, S.; Virtanen, T.; Maunu, S.-L.; Argyropoulos, D.S.; et al. Tosylation and acylation of cellulose in 1-allyl-3-methylimidazolium chloride. Cellulose 2008, 15, 481-488.

173. Schöbitz, M.; Meister, F.; Heinze, T. Unconventional reactivity of cellulose dissolved in ionic liquids. Macromol. Symp. 2009, 280, 102-111. [CrossRef]

174. Gericke, M.; Schaller, J.; Liebert, T.; Fardim, P.; Meister, F.; Heinze, T. Studies on the tosylation of cellulose in mixtures of ionic liquids and a co-solvent. Carbohydr. Polym. 2012, 89, 526-536. [CrossRef] [PubMed]

175. Köhler, S.; Heinze, T. Efficient synthesis of cellulose furoates in 1-N-Butyl-3-methylimidazolium chloride. Cellulose 2007, 14, 489-495. [CrossRef]

176. Barthel, S.; Heinze, T. Acylation and carbanilation of cellulose in ionic liquids. Green Chem. 2006, 8, 301-306. [CrossRef]

177. Schlufter, K.; Schmauder, H.-P.; Dorn, S.; Heinze, T. Efficient homogeneous chemical modification of bacterial cellulose in the ionic liquid 1-N-Butyl-3-methylimidazolium chloride. Macromol. Rapid Commun. 2006, 27, 1670-1676. [CrossRef]

178. Chun-xiang, L.; Huai-yu, Z.; Ming-hua, L.; Shi-yu, F.; Jia-jun, Z. Preparation of cellulose graft poly(methyl methacrylate) copolymers by atom transfer radical polymerization in an ionic liquid. Carbohydr. Polym. 2009, 78, 432-438. [CrossRef]

179. Sui, X.; Yuan, J.; Zhou, M.; Zhang, J.; Yang, H.; Yuan, W.; Wei, Y.; Pan, C. Synthesis of cellulose-graft-poly (N,N-dimethylamino-2-ethyl methacrylate) copolymers via homogeneous ATRP and their aggregates in aqueous media. Biomacromolecules 2008, 9, 2615-2620. [CrossRef] [PubMed]

180. Zhang, J.; Wu, J.; Cao, Y.; Sang, S.; Zhang, J.; He, J. Synthesis of cellulose benzoates under homogeneous conditions in an ionic liquid. Cellulose 2009, 16, 299-308. [CrossRef]

181. Heinze, T.; Dorn, S.; Schöbitz, M.; Liebert, T.; Köhler, S.; Meister, F. Interactions of ionic liquids with polysaccharides-2: Cellulose. Macromol. Symp. 2008, 262, 8-22. [CrossRef]

182. Gericke, M.; Liebert, T.; Heinze, T. Interaction of ionic liquids with polysaccharides, 8 -synthesis of cellulose sulfates suitable for polyelectrolyte complex formation. Macromol. Biosci. 2009, 9, 343-353. [CrossRef] [PubMed]

183. Liu, C.F.; Sun, R.C.; Zhang, A.P.; Ren, J.L. Preparation of sugarcane bagasse cellulosic phthalate using an ionic liquid as reaction medium. Carbohydr. Polym. 2007, 68, 17-25. [CrossRef]

184. Liu, C.F.; Sun, R.C.; Zhang, A.P.; Ren, J.L.; Geng, Z.C. Structural and thermal characterization of sugarcane bagasse cellulose succinates prepared in ionic liquid. Polym. Degrad. Stab. 2006, 91, 3040-3047. [CrossRef]

185. Liu, C.-F.; Zhang, A.-P.; Li, W.-Y.; Yue, F.-X.; Sun, R.-C. Homogeneous modification of cellulose in ionic liquid with succinic anhydride using N-bromosuccinimide as a catalyst. J. Agric. Food. Chem. 2009, 57, 1814-1820. [CrossRef] [PubMed]

186. Li, W.Y.; Jin, A.X.; Liu, C.F.; Sun, R.C.; Zhang, A.P.; Kennedy, J.F. Homogeneous modification of cellulose with succinic anhydride in ionic liquid using 4-dimethylaminopyridine as a catalyst. Carbohydr. Polym. 2009, 78, 389-395. [CrossRef]

187. Liu, C.F.; Zhang, A.P.; Li, W.Y.; Yue, F.X.; Sun, R.C. Succinoylation of cellulose catalyzed with iodine in ionic liquid. Ind. Crops Prod. 2010, 31, 363-369. [CrossRef]

188. Buchanan, C.M.; Buchanan, N.L.; Donelson, M.E.; Gorbunova, M.G.; Kuo, T.; Wang, B. Regioselectively Substituted Cellulose Esters Produced in a Halogenated Ionic Liquid Process and Products Produced Therefrom. Patent WO 2,010,019,245, 20 August 2010.

189. Buchanan, C.M.; Buchanan, N.L.; Guzman-Morales, E. Regioselectively Substituted Cellulose Esters Produced in a Tetraalkylammonium Alkylphosphate Ionic Liquid Process and Products produced Therefrom. U.S. Patent 20,100,267,942, 21 October 2010.

190. Buchanan, C.M.; Buchanan, N.L.; Hembre, R.T.; Lambert, J.L. Cellulose Esters and Their Production in Carboxylated Ionic Liquids. U.S. Patent 20,120,142,910, 5 April 2012.

191. Granström, M.; Mormann, W.; Frank, P. Method of Chlorinating Polysaccharides or Oligosaccharides. Patent WO 2011086082 A1, 21 July 2011.

192. Scheibel, J.J.; Kenneally, C.J.; Menkaus, J.A.; Seddon, K.R.; Chwala, P. Methods for Modifying Cellulosic Polymers in Ionic Liquids. WO 2,007,112,382, 21 July 2007.

193. Zhang, J.; Chen, W.; Feng, Y.; Wu, J.; Yu, J.; He, J.; Zhang, J. Homogeneous esterification of cellulose in room temperature ionic liquids. Polym. Int. 2015, 64, 963-970. [CrossRef] 
194. Buchanan, C.M.; Buchanan, N.L. Production of cellulose esters in the Presence of a Cosolvent. U.S. Patent 20,120,238,742, 13 August 2012.

195. Myllymaki, V.; Aksela, R. Method for Preparing a Cellulose Ether. U.S. Patent 20,070,112,185, 17 May 2007.

196. Mormann, W.; Wezstein, M. Trimethylsilylation of cellulose in ionic liquids. Macromol. Biosci. 2009, 9, 369-375. [CrossRef] [PubMed]

197. Erdmenger, T.; Haensch, C.; Hoogenboom, R.; Schubert, U.S. Homogeneous tritylation of cellulose in 1-butyl-3-methylimidazolium chloride. Macromol. Biosci. 2007, 7, 440-445. [CrossRef] [PubMed]

198. Granström, M.; Olszewska, A.; Mäkelä, V.; Heikkinen, S.; Kilpeläinen, I. A new protection group strategy for cellulose in an ionic liquid: Simultaneous protection of two sites to yield 2,6-di-O-substituted mono- $p$-methoxytrityl cellulose. Tetrahedron Lett. 2009, 50, 1744-1747. [CrossRef]

199. Lv, Y.; Chen, Y.; Shao, Z.; Zhang, R.; Zhao, L. Homogeneous tritylation of cellulose in 1-allyl-3-methylimidazolium chloride and subsequent acetylation: The influence of base. Carbohydr. Polym. 2015, 117, 818-824. [CrossRef] [PubMed]

200. Köhler, S.; Liebert, T.; Heinze, T.; Vollmer, A.; Mischnick, P.; Möllmann, E.; Becker, W. Interactions of ionic liquids with polysaccharides 9 . Hydroxyalkylation of cellulose without additional inorganic bases. Cellulose 2010, 17, 437-448. [CrossRef]

201. Moellmann, E.; Heinze, T.; Liebert, T.; Koehler, S. Homogeneous Synthesis of Cellulose Ethers in Ionic Liquids. U.S. Patent 8,541,571, 24 September 2013.

202. Lehmann, A.; Volkert, B. Method for Producing Polysaccharide Derivatives. U.S. Patent 20120088909, 12 April 2012.

203. Massonne, K.; Stegmann, V.; D'Andola, G.; Mormann, W.; Wezstein, M.; Leng, W. Process for Silylating Cellulose. U.S. Patent 20,090,281,303, 12 November 2009.

204. Holtkötter, T.; Michel, S.; Sonnenberg, G. Process and Apparatus for the Industrial Preparation of Methylhydroxyalkylcellulose. U.S. Patent 6,667,395, 13 December 2003.

205. Medronho, B.; Lindman, B. Brief overview on cellulose dissolution/regeneration interactions and mechanisms. Adv. Colloid Interface Sci. 2015, 222, 502-508. [CrossRef] [PubMed]

206. Liu, Z.; Sun, X.; Hao, M.; Huang, C.; Xue, Z.; Mu, T. Preparation and characterization of regenerated cellulose from ionic liquid using different methods. Carbohydr. Polym. 2015, 117, 99-105. [CrossRef] [PubMed]

207. Sun, L.; Chen, J.Y.; Jiang, W.; Lynch, V. Crystalline characteristics of cellulose fiber and film regenerated from ionic liquid solution. Carbohydr. Polym. 2015, 118, 150-155. [CrossRef] [PubMed]

208. Olsson, C.; Hedlund, A.; Idström, A.; Westman, G. Effect of methylimidazole on cellulose/ionic liquid solutions and regenerated material therefrom. J. Mater. Sci. 2014, 49, 3423-3433. [CrossRef]

209. Michud, A.; Hummel, M.; Sixta, H. Influence of molar mass distribution on the final properties of fibers regenerated from cellulose dissolved in ionic liquid by dry-jet wet spinning. Polymer 2015, 75, 1-9. [CrossRef]

210. Östlund, Å.; Idström, A.; Olsson, C.; Larsson, P.T.; Nordstierna, L. Modification of crystallinity and pore size distribution in coagulated cellulose films. Cellulose 2013, 20, 1657-1667. [CrossRef]

211. Jiang, G.; Huang, W.; Zhu, T.; Zhang, C.; Kumi, A.K.; Zhang, Y.; Wang, H.; Hu, L. Diffusion dynamics of 1-butyl-3-methylimidazolium chloride from cellulose filament during coagulation process. Cellulose 2011, 18, 921-928. [CrossRef]

212. Li, B.; Asikkala, J.; Filpponen, I.; Argyropoulos, D.S. Factors affecting wood dissolution and regeneration of ionic liquids. Ind. Eng. Chem. Res. 2010, 49, 2477-2484. [CrossRef]

213. Mai, N.L.; Ahn, K.; Koo, Y.-M. Methods for recovery of ionic liquids-A review. Process. Biochem. 2014, 49, 872-881. [CrossRef]

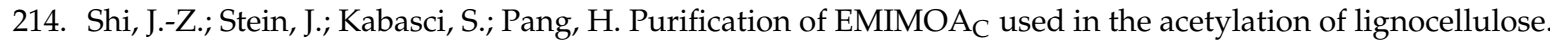
J. Chem. Eng. Data 2013, 58, 197-202. [CrossRef]

215. Huang, K.; Wu, R.; Cao, Y.; Li, H.; Wang, J. Recycling and reuse of ionic liquid in homogeneous cellulose acetylation. Chin. J. Chem. Eng. 2013, 21, 577-584. [CrossRef]

(C) 2017 by the authors. Licensee MDPI, Basel, Switzerland. This article is an open access article distributed under the terms and conditions of the Creative Commons Attribution (CC BY) license (http:/ / creativecommons.org/licenses/by/4.0/). 